\title{
Effects of fatty acids and calf starter form on intake, growth, digestion, and selected blood metabolites in male calves from 0 to 4 months of age
}

\author{
J. D. Quigley, ${ }^{1 *}$ T. M. Hill, ${ }^{1}$ L. E. Hulbert, ${ }^{2}$ T. S. Dennis, ${ }^{1}$ X. F. Suarez-Mena, ${ }^{1}$ and E. M. Bortoluzzi ${ }^{2}$ \\ ${ }^{1}$ Nurture Research Center, Provimi North America, Cargill Animal Nutrition, Brookville, OH 45309 \\ ${ }^{2}$ Department of Animal Sciences and Industry, Kansas State University, Manhattan 66506
}

\section{ABSTRACT}

The objective of this research was to determine if form of calf starter (CS) and addition of a fatty acid blend (FA) influenced intake, growth, digestion, and indices of immune status and stress in calves from 0 to 4 mo of age. Male Holstein calves $[\mathrm{n}=48 ; 41.9 \mathrm{~kg}$ of body weight $(\mathrm{BW})$, standard error $=0.7 ; 2$ to 3 $\mathrm{d}$ of age] were assigned to receive reconstituted whole milk powder $[0.66 \mathrm{~kg}$ of dry matter $(\mathrm{DM}) / \mathrm{d}$ to $39 \mathrm{~d}$, then $0.33 \mathrm{~kg}$ of $\mathrm{DM} / \mathrm{d}$ to weaning at $42 \mathrm{~d}$ ] without or with added FA. Calf starters were textured (pellet, whole oats, whole corn) or pelleted and were offered for ad libitum consumption from 0 to $56 \mathrm{~d}$, then blended with 5\% chopped grass hay and fed from d 57 to 112. Starters contained $20 \%$ crude protein $(\mathrm{CP})$ and 38 to $40 \%$ starch in the DM. From d 0 to 56 , calves were housed individually. From d 57 to 112 , calves were grouped into pens by treatment $(\mathrm{n}=4 /$ pen). Form of CS during the initial $56 \mathrm{~d}$ had no effect on intake or growth, though days with fluid feces (fecal score $\geq 2.5$ ) were greater when calves were fed textured CS. Feeding FA during the initial 56-d increased average daily BW gain, gain-to-feed ratio, and change in hip width, and reduced the number of days calves were treated with antibiotics. During d 57 to 112, CS form had no effects on any performance measure. Adding FA to CS increased average daily BW gain and hip width change, and tended to improve efficiency of BW gain. Totaltract digestibility was estimated at 4,6 , and 8 wk with 5 calves per treatment, and at 10,13, and 16 wk of age using pen ( $\mathrm{n}=3$ per treatment) as the experimental unit. Feeding FA increased or tended to increase totaltract digestion of DM, organic matter, starch, neutral detergent fiber (NDF), acid detergent fiber (ADF), CP, and fat at one or more measurement periods. Calves fed a textured CS increased or tended to increase digestion of DM, organic matter, starch, sugar, NDF, ADF, and

Received March 26, 2019.

Accepted May 16, 2019.

*Corresponding author: jquigley@provimi-na.com
CP during wk 6 and 8. However, during the second 56-d phase, feeding textured CS reduced or tended to reduce digestion of DM, organic matter, starch, NDF, ADF, and fat during wk 13 and 16. Inclusion of FA in milk increased serum bactericidal activity before weaning. Serum haptoglobin concentration increased $3 \mathrm{~d}$ postweaning when calves were fed textured CS. Feeding FA improved animal health, digestion, and performance. Form of CS had few effects on animal performance. Key words: calf, calf starter, fatty acid, digestion

\section{INTRODUCTION}

Young dairy calves experience dramatic changes in source and digestion of ingested nutrients in the first 4 mo of life. Transition from a liquid diet to one containing grains and forages requires fundamental change and adaptation in the gastrointestinal system to allow ruminal fermentation and intestinal digestion of ingested nutrients (Guilloteau et al., 2009a).

Changing nutrient source, including liquid intake before weaning and other management factors, may affect ontogenesis of total-tract digestion (TTD) of nutrients (Hill et al., 2010, 2016a,b; Dennis et al., 2017, 2018). Physical form of calf starter (CS) has also been shown to influence TTD before and after weaning (Quigley et al., 2018).

Growth, digestion, and immune responses in young calves are influenced by fatty acids, including butyrate (Guilloteau et al., 2009b; Górka et al., 2011a,b), linoleic and linolenic acids (Kadkhodaya et al., 2017), and medium-chain triglycerides (Hill et al., 2009, 2011a; Garcia et al., 2015). Although the exact mode of action has not been fully defined, blends of fatty acids, including butyrate, medium-chain fatty acids from coconut oil and linolenic acid, successfully improved growth, efficiency, and health indices of calves pre- and postweaning (Hill et al., 2011a,b; Esselburn et al., 2013).

Digestibility of nutrients may be affected by ration form (Porter et al., 2007), though others have reported no effect of pelleted versus texturized CS on digestion or growth when similar ingredients were included in 
each form (Coverdale et al., 2004; Bach et al., 2007; Nejad et al., 2012). Recently, Quigley et al. (2018) reported that digestion of most nutrients was increased when calves were fed a texturized CS containing $41 \%$ starch compared with a pelleted CS containing $10 \%$ starch at 5 and 8 wk of age. Differences in digestion in this study may have been due to differences in nutrient content, ingredients used in the feeds, or both factors.

Weaning and comingling of calves are potentially stressful events in the young calf's life. These events may increase circulation of stress hormones such as cortisol (Kim et al., 2011), increase acute phase proteins (Kim et al., 2011; Yun et al., 2014), or impair measures of immunity (Hulbert et al., 2011; Hulbert and Ballou, 2012). Feed composition may alleviate or exacerbate stress responses due to weaning and comingling. For example, animals with SARA exhibit indices of stress such as increased acute phase protein concentration (Danscher et al., 2011; Ceciliani et al., 2012). Thus, it seems possible that stress responses due to weaning or grouping could be influenced by diet as intake of dry feed may vary following these management changes.

Our objective was to determine if form of CS and inclusion of a fatty acid blend (FA) in the diet would influence growth and digestion of young calves. Further, we investigated the effect of diet and FA addition on changes in cortisol and haptoglobin concentrations and indices of immune competence when calves were weaned and after comingling.

\section{MATERIALS AND METHODS}

Holstein bull calves $(\mathrm{n}=48 ; 41.9 \mathrm{~kg}$ of $\mathrm{BW}$; $\mathrm{SE}=$ 0.7 ) were born at a single dairy farm and fed pooled colostrum 3 times in the first $24 \mathrm{~h}$. Thereafter, they were fed milk $(2 \mathrm{~L}$ per feeding, $2 \times / \mathrm{d})$ until they were transported $3.5 \mathrm{~h}$ to the experimental site. Calves were 2 to $3 \mathrm{~d}$ of age on initiation of the study. Calves were weighed on the day after arrival, blood was collected by jugular venipuncture, and serum was separated by centrifugation at 3,000 $\times g$ at room temperature for 15 min (VWR, Batavia, IL). Total serum protein concentration was estimated using an optical refractometer (ATAGO U.S.A. Inc., Bellevue, WA).

All calves were fed $0.66 \mathrm{~kg}$ of $\mathrm{DM} / \mathrm{d}$ of whole milk powder $(25 \% \mathrm{CP}, 29 \%$ fat) to $39 \mathrm{~d}$, then $0.33 \mathrm{~kg}$ of DM/d to weaning at $42 \mathrm{~d}$. Milk powder was reconstituted to $14 \%$ solids with water $\left(45^{\circ} \mathrm{C}\right)$ and fed at approximately 0600 and $1600 \mathrm{~h}$ to $\mathrm{d} 39$, then at $0600 \mathrm{~h}$ from $\mathrm{d} 40$ to 42 via buckets with nipples. Calves were assigned randomly to a $2 \times 2$ factorial arrangement of CS form and added FA. A supplement without $(\mathbf{F A}-)$ or with $($ FA+) fatty acid blend (NeoTec5g Milk Supplement, Provimi, Brookville, $\mathrm{OH}$ ) was added to milk at $25 \mathrm{~g} / \mathrm{d}$
Table 1. Ingredient composition of experimental calf starters

\begin{tabular}{lrrrr}
\hline & \multicolumn{4}{c}{ Treatment $^{1}$} \\
\cline { 2 - 5 } Item & FA-TXS & FA+TXS & FA-PS & FA+PS \\
\hline Ingredient, \% as fed & & & & \\
Corn, whole & 37.00 & 37.00 & & \\
Oats, whole & 25.00 & 25.00 & & \\
Molasses & 3.00 & 3.00 & & \\
Within pellet & & & 44.30 & 44.30 \\
Corn, rolled & & & 25.36 & 25.36 \\
$\quad$ Soybean meal & 24.86 & 24.86 & 1.17 & 20.00 \\
$\quad$ Wheat middlings & 4.49 & 4.49 & 20.17 \\
Calcium carbonate & 1.21 & 1.21 & 6.67 & 6.67 \\
Additives & & & & \\
Molasses, dry & 4.42 & 3.67 & 2.50 & 2.50 \\
\hline
\end{tabular}

${ }^{1}$ Treatment: $\mathrm{FA}-=$ no added fatty acid blend; $\mathrm{FA}+=$ added fatty acid blend; TXS = texturized calf starter; PS = pelleted calf starter.

${ }^{2}$ Salt, monocalcium phosphate, maltodextrin, alfalfa meal, magnesium oxide, fat, premix containing diflubenzuron (Clarifly, Central Life Sciences, Schaumburg, IL), premix containing decoquinate (Zoetis, Kalamazoo, MI), aroma, calcium propionate, and pellet binder. NeoTec5g was added to FA+ calf starters.

from d 0 to 39 and $12.5 \mathrm{~g} / \mathrm{d}$ during d 40 to 42 . Calves were also assigned randomly to receive either a pelleted starter (PS) or texturized starter (TXS; Table 1) to d 56 (nursery phase). Pelleted starter and pellets in TXS were $5 \mathrm{~mm}$ in diameter. From d 57 to 112 (grower phase), starters were mixed with medium-quality, chopped (approximately $2.5 \mathrm{~cm}$ long) grass hay in the ratio of 95:5. Amount of feed offered and previous day feed refusals were weighed once daily to determine daily feed intake. Starters varied by ingredient (Table 1) but contained similar nutrient concentrations (Table 2). Starters and water were offered once daily at approximately 0800 h. During d 0 to 42 , calves assigned to FA+PS and FA+TXS treatments were fed CS without added FA (i.e., FA-PS and FA-TXS starters, respectively) so FA was fed only in the milk. On d 43, the CS offered to calves on these treatments was switched to FA+PS and FA+TXS, respectively, so that FA was provided from CS.

Calves were housed in a curtain-sided, naturally ventilated nursery with no added heat in $1.2-\times 2.4-\mathrm{m}$ individual pens bedded with wheat straw for the first 56 d. Dividers were metal fence panels, which allowed individual calves to make contact with each other and visually interact. During the nursery phase, treatments were randomly assigned within the barn. Calves were dehorned and castrated at d 36 . On d 56, calves were grouped randomly within treatment and moved to super hutches $(\mathrm{n}=4$ calves per hutch). Super hutches had $6.5 \mathrm{~m}^{2}$ of outside pen space and $1.35 \mathrm{~m}^{2}$ of inside pen space bedded with wheat straw. Every other bag of starter and every bale of hay was sampled and composited for nutrient analysis. All animals were cared 
Table 2. Nutrient composition of experimental feeds

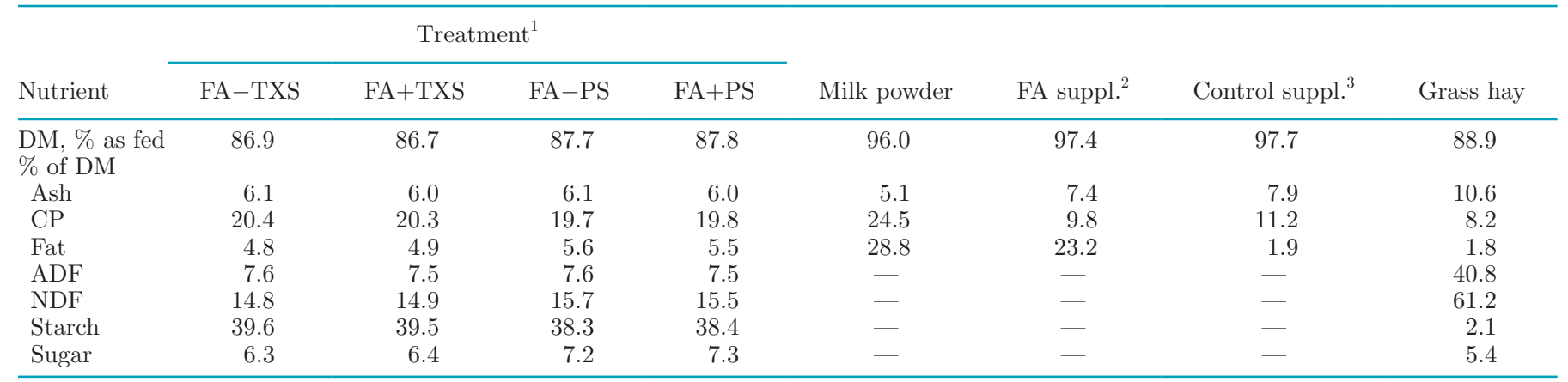

${ }^{1}$ Treatment: $\mathrm{FA}-=$ no added fatty acids; $\mathrm{FA}+=$ added fatty acids; TXS $=$ texturized calf starter; PS $=$ pelleted calf starter.

${ }^{2}$ FA suppl. = fatty acid supplement containing functional fatty acids (NeoTec5g Milk Supplement, Provimi, Brookville, OH). Ingredients included whey, vitamins, and trace minerals, lasalocid premix (Zoetis Inc., Kalamazoo, MI), and NeoTec5g.

${ }^{3}$ Control suppl. $=$ supplement without added NeoTec5g.

for as described in the Guide for the Care and Use of Agricultural Animals in Research and Teaching (FASS, 2010).

Calves were weighed initially and every $7 \mathrm{~d}$ thereafter to $56 \mathrm{~d}$, then on $\mathrm{d} 84$ and 112. Hip widths of the calves were measured with a caliper and BCS was estimated initially and every $14 \mathrm{~d}$ to $56 \mathrm{~d}$, then on $\mathrm{d} 84$ and 112 . Body condition score was based on a 1 to 5 system using 0.25-unit increments, with 1 being emaciated to 5 being obese (Wildman et al., 1982) and were based on changes around the vertical and transverse processes of the spine as palpated by one experienced technician. Measured BW, BCS, and hip widths taken on d 56, 84, and 112 were averaged by pen. Feces were scored daily during the first 56-d period on a scale of $1=$ firm, normal, $2=$ less firm, normal, $3=$ thick, batterlike, $4=$ thin, batter-like, $5=$ watery; modified from Kertz and Chester-Jones (2004). Intermediate scores of $1.5,2.5,3.5$, and 4.5 were recorded as appropriate. An abnormal fecal day was recorded when fecal score was $\geq 3$ and a fluid fecal day was recorded when fecal score was $\geq 2.5$. Fluid and abnormal fecal days were used to identify conditions of potential intestinal fermentation or maldigestion (fluid) and diarrhea due to disease (abnormal).

On d 21 to 25 (wk 4) and 34 to 38 (wk 6), feces were collected by rectal palpation from 5 calves randomly selected per treatment to estimate digestibility. During those $5 \mathrm{~d}$ and the preceding $7 \mathrm{~d}$, chromic oxide was added to the milk at each feeding as a digesta flow marker as described by Hill et al. (2016a). Starter was sampled daily during each 5 -d period and pooled, and milk powder was sampled. Pooled fecal samples were sub-sampled and analyzed for chromium ash relative to concentration in milk and feed intake over the 5-d period to estimate digestibility and fecal output.
Fecal grab samples were also collected from the same 5 calves per treatment on d 49 to 53 (wk 8) to estimate digestibility. Also, during d 62 to 66 (wk 10), d 83 to 87 (wk 13), and d 104 to 108 (wk 16), 4 fecal samples were taken daily from the super hutch floor with care not to sample floor materials and composited by pen and week to estimate digestibility. Acid insoluble ash was used as a fecal output marker for all fecal collections made after $\mathrm{d} 42$. The nursery phase of the trial (d 0 to 56) was conducted between January 16 and March 13, 2018. The grower phase of the trial (d 57 to 112 ) was conducted between March 13 and May 8, 2018.

Composites of feeds, refused feed, and feces were analyzed for DM (oven method 930.15; AOAC International, 2016), ash (oven method 942.05; AOAC International, 2016), CP (Kjeldahl method 988.05; AOAC International, 2016), fat ether extract (alkaline treatment with Roese-Gottlieb method 932.06 for milk powder, diethyl ether extraction method 2003.05 for starters and hay; AOAC International, 2016), NDF with ash by the procedure of Van Soest et al. (1991) without sodium sulfite or $\alpha$-amylase, ADF with ash (Robertson and Van Soest, 1981), starch ( $\alpha$-amylase method; Hall, 2009), sugar (colormetric method; Dubois et al., 1956), Cr (Bouchard et al., 1973), and acid-insoluble ash (Van Keulen and Young, 1977). Organic matter was calculated as DM - ash.

Approximately $10 \mathrm{~mL}$ of blood was collected by jugular venipuncture from all calves at -1 and +3 after weaning (41 and $45 \mathrm{~d}$ of study) and -1 and $+6 \mathrm{~d}$ after moving from individual pens in the nursery barn to group pens in the grower facility ( 55 and $62 \mathrm{~d}$ of study). Blood was collected at approximately $1000 \mathrm{~h}$ each d into evacuated tubes without anticoagulant and allowed to clot for approximately $1 \mathrm{~h}$. Serum was separated by centrifugation at $3,000 \times g$ for $20 \mathrm{~min}$ at room 
temperature and placed in labeled tubes and frozen at $-20^{\circ} \mathrm{C}$ until shipped to the laboratory for analysis of haptoglobin, serum bactericidal activity (SBA), and cortisol.

Serum bactericidal activity against a live culture of bacteria was measured using methods similar to bactericidal activity of plasma (Crokaert et al., 1988; Moisá et al., 2018). Serum was incubated with Escherichia coli 8739 at a 1:8 ratio for $10 \mathrm{~min}$. Then, it was cultured over tryptic soy agar plates (Sigma-Aldrich). Plates were incubated at $37.5^{\circ} \mathrm{C}$ for $24 \mathrm{~h}$ and number of colony-forming units was estimated. Percent of colonyforming units eliminated by serum was calculated.

Haptoglobin concentrations determined as described in Cooke and Arthington (2013). Serum samples (10 $\mu \mathrm{L}$ ) were incubated with $7.5 \mathrm{~mL}$ of O-dianisidine solution for $45 \mathrm{~min}$ at $37.5^{\circ} \mathrm{C}$, followed by addition of $25 \mu \mathrm{L}$ of hemoglobin solution and incubation for an additional $45 \mathrm{~min}$ at $37.5^{\circ} \mathrm{C}$. Thereafter, $100 \mu \mathrm{L}$ of hydrogen peroxide solution was added and incubated for $1 \mathrm{~h}$ at room temperature. Optical density was measured at $450 \mathrm{~nm}$ using a microplate reader. Intra- and interassay coefficients of variation ranged from 3 to $7.5 \%$, respectively.

Cortisol was measured in $15 \mu \mathrm{L}$ of serum using a commercially available ELISA kit (DetectX, Arbor Assays, Ann Arbor, MI). Optical density was measured at 450 $\mathrm{nm}$ and concentrations were calculated using computer software (elisanalysis.com). Intra- and interassay coefficients of variation ranged from 4 to $6 \%$, respectively.

Data were analyzed as a completely random design with a $2 \times 2$ factorial arrangement of treatments with calf as experimental unit during the first 56-d nursery phase and pen as experimental unit during the second 56 -d grower phase. The Mixed procedure of SAS (version 8, SAS Institute, Cary, NC) was used. Repeated measures were incorporated into models when variables were measured over time. An auto-regressive type 1 covariance matrix was employed as determined using Akaike's information criteria for most variables. Orthogonal contrast statements were constructed to separate differences due to FA provision, CS form, and interaction; differences were declared at $P \leq 0.05$ and tendencies at $P \leq 0.10$. When $\mathrm{FA} \times \mathrm{CS}$ form interaction was significant, means were separated using the PDIFF option of the Mixed procedure. Initial calf BW varied significantly among treatments; therefore, performance measurements for the first 56-d nursery phase were covariately adjusted for initial BW. Digestion estimates, blood data, and performance during the second 56-d grower phase were not adjusted.

Fecal starch and apparent total-tract starch digestion (TTSD) were analyzed as a repeated measures ANOVA using PROC Mixed procedure of SAS using treatment (form of CS and FA), week, and week $\times$ treatment interaction in the model. Analyses were conducted using individual animal as the experimental unit ( $\mathrm{n}=20$ observations per week) for wk 4,6 , and 8 , and pen as the experimental unit for wk 10, 13, and 16 ( 4 calves/pen, $\mathrm{n}=12$ observations per week). Unstructured covariance structure produced the lowest Akaike information criteria and was used in the analyses.

Apparent TTSD was also regressed on fecal starch using Proc REG of SAS. In the nursery phase, the model included a form of starter indicator variable, whereas the model in the grower phase contained only fecal starch as an independent variable. Residuals were plotted versus predicted values to evaluate potential bias. Variables were declared significant at $P \leq 0.05$, and trends were reported when $P \leq 0.10$.

\section{RESULTS}

\section{Animal Intake and Performance}

Ingredient and nutrient composition of feeds are in Tables 1 and 2, respectively. Average temperature during the nursery phase was $1^{\circ} \mathrm{C}$ (range from -20 to $22^{\circ} \mathrm{C}$ ) with an average humidity of $84 \%$ (range from 36 to $100 \%$ ). Average temperature during the grower phase was $7^{\circ} \mathrm{C}$ (range from -8 to $28^{\circ} \mathrm{C}$ ) with an average humidity of $73 \%$ (range from 17 to $100 \%$ ).

Least squares means of initial BW were 44.5, 42.6, 44.0 , and $41.3 \mathrm{~kg}$ for calves on FA-TXS, FA+TXS, $\mathrm{FA}-\mathrm{PS}$, and FA+PS, respectively $(\mathrm{SE}=1.10$; FA effect, $P<0.04)$. Therefore, performance measures during the nursery phase of the experiment were covariately adjusted. Intake and performance of calves during the nursery and grower phases are in Tables 3 and 4, respectively. No calves died or were removed during the study. During the nursery phase, calves fed FA+ had greater final BW, ADG, gain-to-feed ratio, and hip width change, and fewer medical days than calves fed FA-. Calves fed TXS had lower final BCS and final hip width (though changes in BCS and hip width did not differ), and greater number of days with fluid feces (fecal score $\geq 2.5$ ). There were no interactions between FA and CS form. During the grower phase, calves fed $\mathrm{FA}+$ had greater final BW, ADG, final hip width, and change in hip width, and tended to have improved gainto-feed ratio. Calves fed TXS had greater initial and final hip width and lower initial BCS. Other indices of intake, growth, or efficiency did not differ among treatments.

Least squares means of weekly starter DMI, calf BW, and number of days with fluid feces during the nursery phase are in Figures 1 to 3, respectively. Changes with 
Table 3. Performance of calves fed calf starter with different physical form and whole milk powder without or with fatty acid blend during the nursery phase of the experiment ( 0 to $56 \mathrm{~d})$

\begin{tabular}{|c|c|c|c|c|c|c|c|c|}
\hline Item $^{1}$ & \multicolumn{4}{|c|}{ Treatment $^{2}$} & SEM & \multicolumn{3}{|c|}{ Contrast $^{3}$} \\
\hline Initial BW, kg & 43.2 & 43.2 & 43.2 & 43.2 & - & - & - & - \\
\hline Final BW, kg & 78.0 & 83.9 & 81.5 & 84.3 & 1.51 & 0.19 & 0.01 & 0.28 \\
\hline $\mathrm{ADG},{ }^{4} \mathrm{~kg} / \mathrm{d}$ & 0.62 & 0.73 & 0.69 & 0.73 & 0.032 & 0.26 & 0.02 & 0.35 \\
\hline Milk powder DMI, $\mathrm{kg} / \mathrm{d}$ & 0.49 & 0.49 & 0.49 & 0.49 & - & - & - & - \\
\hline Initial hip width, cm & 17.4 & 17.5 & 18.0 & 17.7 & 0.162 & 0.01 & 0.51 & 0.14 \\
\hline Final hip width, cm & 21.1 & 21.9 & 22.1 & 22.2 & 0.24 & 0.01 & 0.06 & 0.11 \\
\hline Hip width change, $\mathrm{cm}$ & 3.7 & 4.4 & 4.0 & 4.5 & 0.25 & 0.45 & 0.03 & 0.56 \\
\hline Initial BCS & 2.09 & 2.09 & 2.11 & 2.09 & 0.039 & 0.77 & 0.84 & 0.69 \\
\hline Final BCS & 2.16 & 2.23 & 2.32 & 2.32 & 0.037 & 0.001 & 0.31 & 0.34 \\
\hline BCS change ${ }^{7}$ & 0.07 & 0.14 & 0.20 & 0.23 & 0.213 & 0.57 & 0.82 & 0.93 \\
\hline Abnormal fecal days ${ }^{8}$ & 0.1 & 0.0 & 0.0 & 0.0 & 0.02 & 0.98 & 0.23 & 0.27 \\
\hline
\end{tabular}

${ }^{1}$ Dependent variables except initial serum protein were covariately adjusted for initial BW.

${ }^{2}$ Treatment: whole milk powder without $(\mathrm{FA}-)$ or with $(\mathrm{FA}+)$ fatty acid blend, texturized starter (TXS), or pelleted starter (PS). From d 0 to 42 , all calves were fed FA - calf starters so that all FA were supplied from milk powder. On d 43 to 56 , calves on FA+ treatments were switched to starters containing fatty acid blend.

${ }^{3}$ Contrast: effect of calf starter form (pelleted vs. texturized; Form), inclusion of fatty acid blend (FA), and interaction (Int.).

${ }^{4}$ Significant effect of week $(P<0.01)$.

${ }^{5}$ Body weight gain divided by milk powder plus starter intake.

${ }^{6}$ Significant interaction of week $\times$ treatment $(P<0.01)$.

${ }^{7}$ Total change in BCS over the 56-d period. Body condition score was based on a 1 to 5 system using 0.25 -unit increments, with 1 being emaciated to 5 being obese.

${ }^{8}$ Total number of days per week that calves had fecal score $\geq 3$.

${ }^{9}$ Number of days per week that calves had fecal score $\geq 2.5$.

${ }^{10}$ Number of days per week that calves were treated with antibiotics.

increasing age were significant for all variables. Calf starter intake increased with advancing age, but did not differ by treatment. Body weights were greater in calves fed FA+ from 1 to 8 wk. Also, calves fed FA-PS had greater or tended to have greater BW than calves fed FA-TXS from 6 to 8 wk (Figure 2). Days with fluid

Table 4. Performance of calves fed calf starter with different physical form and calf starter without or with fatty acid blend during the grower phase of the experiment (57 to $112 \mathrm{~d}$ )

\begin{tabular}{|c|c|c|c|c|c|c|c|c|}
\hline Item & \multicolumn{4}{|c|}{ Treatment $^{1}$} & SEM & \multicolumn{3}{|c|}{ Contrast $^{2}$} \\
\hline Initial BW, kg & 79.6 & 83.4 & 82.7 & 82.2 & 1.35 & 0.49 & 0.24 & 0.15 \\
\hline $\mathrm{ADG}, \mathrm{kg} / \mathrm{d}$ & 1.07 & 1.15 & 1.03 & 1.17 & 0.017 & 0.69 & 0.001 & 0.11 \\
\hline DMI, kg/d & 3.38 & 3.22 & 3.21 & 3.08 & 0.209 & 0.50 & 0.50 & 0.95 \\
\hline DMI, $\%$ of BW & 3.09 & 2.84 & 2.87 & 2.72 & 0.157 & 0.32 & 0.25 & 0.77 \\
\hline Final hip width, cm & 26.0 & 26.9 & 26.7 & 27.5 & 0.25 & 0.04 & 0.01 & 0.85 \\
\hline Hip width change, $\mathrm{cm}$ & 4.7 & 5.1 & 4.5 & 5.5 & 0.10 & 0.25 & 0.001 & 0.02 \\
\hline Initial BCS & 2.2 & 2.2 & 2.3 & 2.3 & 0.05 & 0.02 & 0.83 & 0.62 \\
\hline Final BCS & 2.8 & 2.7 & 2.9 & 2.7 & 0.06 & 0.48 & 0.11 & 0.70 \\
\hline BCS change $^{4}$ & 0.6 & 0.5 & 0.5 & 0.4 & 0.07 & 0.26 & 0.12 & 0.99 \\
\hline
\end{tabular}

${ }^{1}$ Treatment: calf starter without $(\mathrm{FA}-)$ or with $(\mathrm{FA}+)$ fatty acid blend, texturized starter (TXS), or pelleted starter (PS).

${ }^{2}$ Contrast: effect of calf starter form (pelleted vs. texturized; Form), inclusion of fatty acid blend (FA), and interaction (Int.).

${ }^{3} \mathrm{BW}$ gain divided by DMI.

${ }^{4}$ Total change in BCS over the 56-d period. Body condition score was based on a 1 to 5 system using 0.25 -unit increments, with 1 being emaciated to 5 being obese. 


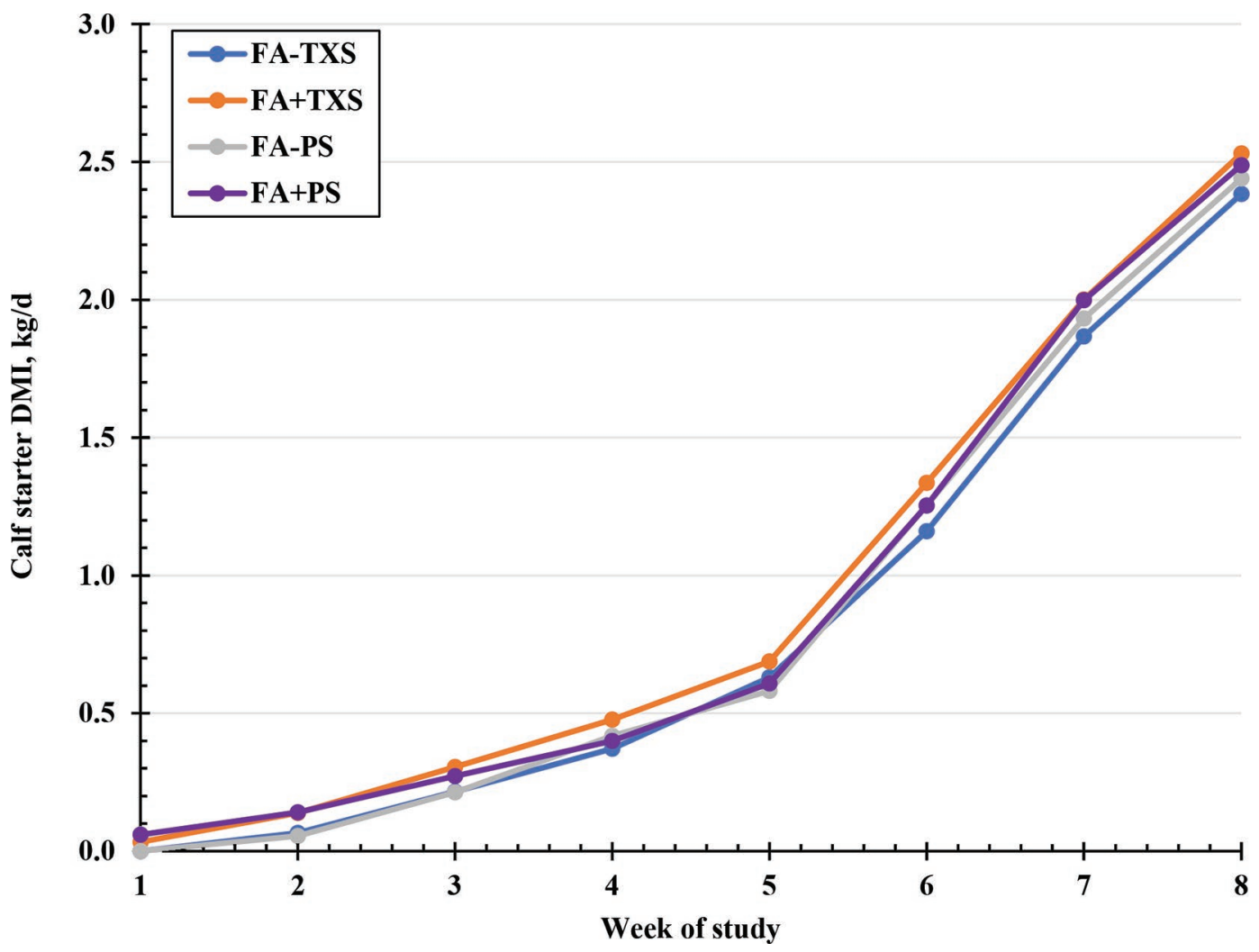

Figure 1. Least squares means of calf starter DMI $(\mathrm{kg} / \mathrm{d})$ in calves fed diets without $(\mathrm{FA}-)$ or with $(\mathrm{FA}+)$ fatty acid blend and texturized (TXS) or pelleted (PS) calf starter during the first 56-d period. Least squares means were covariately adjusted for initial BW. SE $=0.09$.

feces were affected by a week $\times$ treatment interaction $(P<0.001)$. Calves fed TXS had greater number of days with fluid feces from wk 4 to 7 (Figure 3).

\section{Nutrient Digestion}

Digestion of all nutrients except sugar changed with advancing age in the nursery phase $(P<0.01$; Table $5)$. Treatment $\times$ measurement period interaction was significant only for $\mathrm{CP}(P<0.003)$. Digestion of DM and OM declined from 4 to $8 \mathrm{wk}$, whereas TTD of $\mathrm{CP}$, starch, and fat were similar at 4 and $6 \mathrm{wk}$, but declined from wk 6 to 8. Digestion of ADF increased from wk 4 to 6 , then did not change. Digestion of NDF increased to $6 \mathrm{wk}$, then declined at $8 \mathrm{wk}$. During the grower phase, TTD digestion of DM, OM, CP, and starch were similar at 10 and $13 \mathrm{wk}$, but were lower at 16 wk. Digestion of ADF increased from wk 10 to 13, then was constant. Digestion of NDF was higher at 13 wk compared with wk 10 and 16.

During wk 4, adding FA to milk increased digestion of DM, OM, starch, and CP, and tended to increase digestion of sugar, NDF, and fat (Table 6). Form of starter had no effect on TTD of any nutrient at $4 \mathrm{wk}$.
At 6 and 8 wk, FA addition to CS increased or tended to increase TTD of DM, OM, NDF, and ADF. Digestion of CP tended to be greater when calves were fed FA+ at $6 \mathrm{wk}$ but not at 8 wk. At $6 \mathrm{wk}$, TTD of $\mathrm{DM}, \mathrm{OM}$, starch, and sugar were higher or tended to be higher when calves were fed TXS. At 8 wk, TTD of $\mathrm{DM}, \mathrm{OM}$, sugar, $\mathrm{NDF}, \mathrm{ADF}$, and $\mathrm{CP}$ were greater when calves were fed TXS.

At $10 \mathrm{wk}$, feeding FA in CS increased TTD of DM and $\mathrm{OM}$ and tended to increase sugar digestion (Table 7). Calves fed PS had greater TTD of DM at 10 wk. An interaction of form $\times$ FA for sugar was significant at 10 wk, indicating that calves fed FA-PS had the lowest sugar digestion $(P<0.05)$.

At 13 wk, calves fed FA+ had greater TTD of DM, $\mathrm{OM}$, and NDF and tended to have greater TTD of fat. Also, calves fed PS had greater TTD of DM, OM, starch, NDF and fat compared with calves fed TXS. A form $\times$ FA interaction was significant for sugar during wk 13, indicating that calves fed FA+TXS had lower sugar TTD than other treatments.

Finally, at 16 wk, calves fed FA + had greater digestion of DM, OM, NDF, ADF, and CP compared with calves fed FA-. Total-tract digestion of sugar tended 


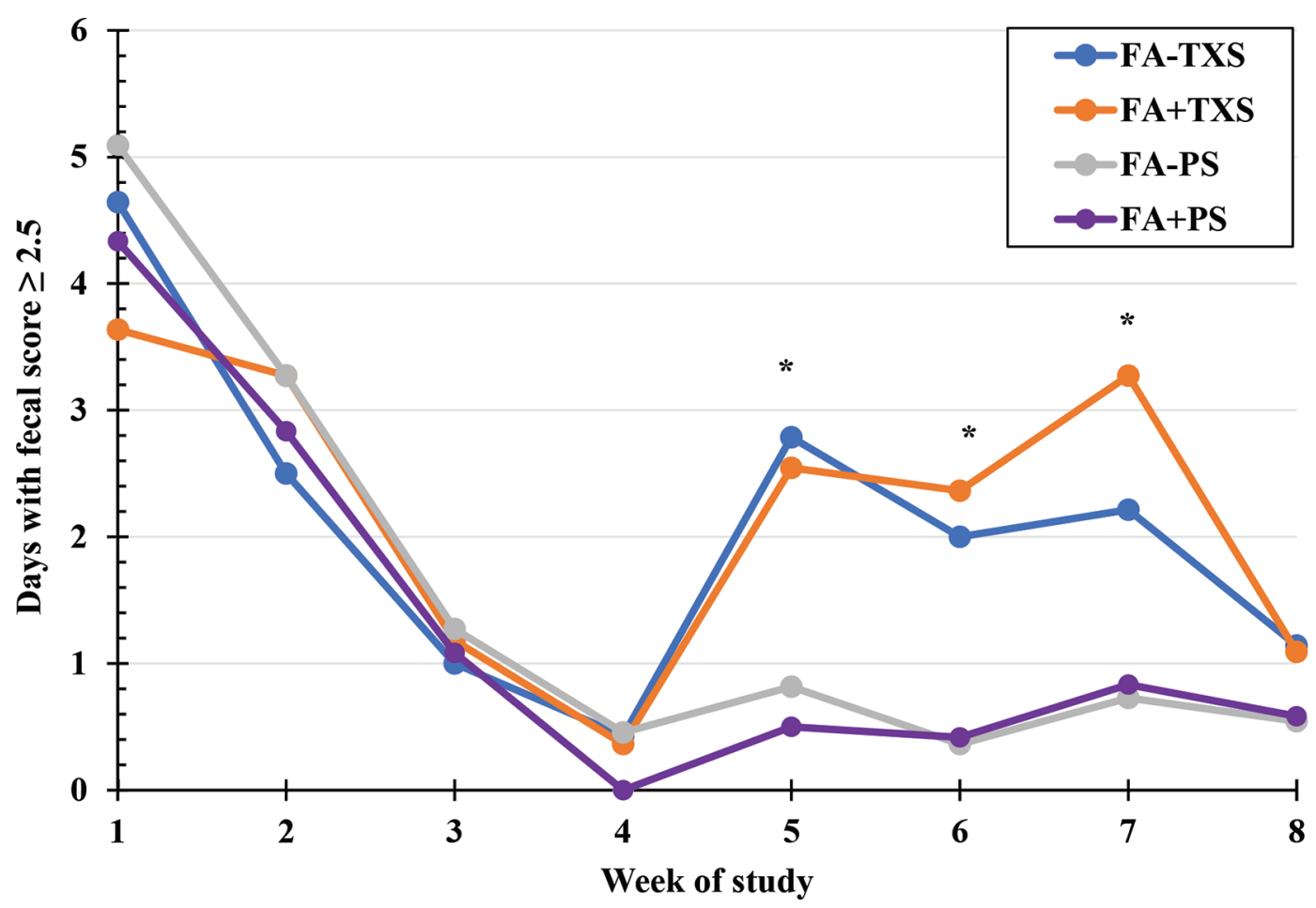

Figure 3. Least squares means of days that calves had fecal scores $\geq 2.5$ by week and treatment in calves fed diets without (FA-) or with $(\mathrm{FA}+)$ fatty acid blend and texturized (TXS) or pelleted (PS) calf starter. SE $=0.43$. Fecal score: $1=$ firm, normal; $2=$ less firm, normal; $3=$ thick, batter-like; $4=$ thin, batter-like; $5=$ watery. ${ }^{*}$ Within week, TXS $>$ PS, $P<0.05$.

to be greater when calves were fed FA+. Feeding PS increased digestion of starch and reduced digestion of $\mathrm{ADF}$ and CP compared with TXS at 16 wk. Organic matter digestion tended to be lower when calves were fed PS at 16 wk.

\section{Fecal Starch and Starch Digestion}

There were no interactions of starter form, FA, or form $\times$ blend $\times$ week for either fecal starch or TTSD, so main effects of starter form and FA are presented. Fecal starch was affected by week and a form $\times$ week interaction during the nursery phase. Fecal starch increased with week when calves were fed TXS, but there was no significant change in fecal starch after 6 wk when calves were fed PS (Figure 4). Calves fed TXS had greater concentrations of fecal starch at $8 \mathrm{wk}$. During the grower phase, fecal starch did not change in calves fed PS, but increased with increasing age in calves fed TXS. Throughout the grower phase, calves fed TXS had greater (wk 13, 16) or tended (wk 10) to have greater concentrations of fecal starch compared with calves fed PS. The FA had no effect on fecal starch in either the nursery or grower phases.

Similar to observations with fecal starch, TTSD was affected by week, treatment, and a week $\times$ treatment interaction. Starch digestion during the nursery phase declined from 4 to 6 wk and did not change at 8 wk in calves fed PS (Figure 5). Apparent TTSD in calves fed TXS did not change from 4 to $6 \mathrm{wk}$, but then declined at 8 wk. Starch digestion was greater in calves fed TXS at $6 \mathrm{wk}$ and tended to be greater in calves fed PS at 8 wk. During the grower phase, TTSD did not change with advancing age in calves fed PS, but declined in calves fed TXS from 10 to 16 wk. Apparent TTSD was greater $(P<0.05)$ or tended $(P<0.10)$ to be greater in calves fed PS throughout the grower phase. Addition of FA improved TTSD by $0.88 \%(P<0.04)$ during the nursery phase, but had no effect on TTSD during the grower phase.

The relationship between TTSD and fecal starch varied by age. In the nursery phase (Figure $6 \mathrm{~A}$ ), regression of TTSD on fecal starch included CS form and CS form $x$ fecal starch interaction. Decreasing TTSD resulted in greater fecal starch in both CS forms, but calves fed TXS had greater fecal starch at a given TTSD compared with calves fed PS $(P<0.01)$. In the grower phase (wk 10 to 16), there was no effect of treatment, and decreasing TTSD increased fecal starch (Figure 7A). Evaluation of residuals in nursery (Figure 6B) and grower (Figure 7B) suggest minimal bias in regression analyses. 
Table 5. Least squares means of apparent total-tract digestion by measurement period during the nursery $(0$ to 8 wk) and grower ( 8 to $16 \mathrm{wk}$ ) phases

\begin{tabular}{lcccccccc}
\hline \multicolumn{7}{c}{ Age, wk } & \multicolumn{7}{c}{ Nutrient $^{1}$} \\
\cline { 2 - 8 } & DMD & OMD & CPD & ADFD & NDFD & STAD & SUGD & FATD \\
\hline 4 & $91.9^{\mathrm{a}}$ & $92.2^{\mathrm{a}}$ & $89.6^{\mathrm{a}}$ & $13.5^{\mathrm{a}}$ & $21.5^{\mathrm{a}}$ & $98.6^{\mathrm{a}}$ & $97.7^{\mathrm{de}}$ & $98.4^{\mathrm{a}}$ \\
6 & $89.1^{\mathrm{b}}$ & $89.3^{\mathrm{b}}$ & $88.4^{\mathrm{a}}$ & $35.0^{\mathrm{b}}$ & $45.4^{\mathrm{b}}$ & $98.2^{\mathrm{a}}$ & $98.3^{\mathrm{d}}$ & $96.9^{\mathrm{a}}$ \\
8 & $78.5^{\mathrm{c}}$ & $79.2^{\mathrm{c}}$ & $74.6^{\mathrm{b}}$ & $31.3^{\mathrm{b}}$ & $36.4^{\mathrm{c}}$ & $97.2^{\mathrm{b}}$ & $97.0^{\mathrm{e}}$ & $85.4^{\mathrm{b}}$ \\
$\mathrm{SE}$ & 0.72 & 0.72 & 0.85 & 3.17 & 2.86 & 0.29 & 0.48 & 0.67 \\
& & & & & & & & \\
10 & $78.3^{\mathrm{a}}$ & $79.4^{\mathrm{a}}$ & $78.7^{\mathrm{ab}}$ & $25.5^{\mathrm{d}}$ & $38.1^{\mathrm{a}}$ & $97.2^{\mathrm{a}}$ & $96.4^{\mathrm{a}}$ & $79.5^{\mathrm{a}}$ \\
13 & $78.6^{\mathrm{a}}$ & $80.1^{\mathrm{a}}$ & $79.5^{\mathrm{a}}$ & $30.0^{\mathrm{e}}$ & $45.1^{\mathrm{b}}$ & $96.8^{\mathrm{a}}$ & $97.8^{\mathrm{b}}$ & $74.0^{\mathrm{b}}$ \\
SE & $76.1^{\mathrm{b}}$ & $77.3^{\mathrm{b}}$ & $77.0^{\mathrm{b}}$ & $30.9^{\mathrm{e}}$ & $38.3^{\mathrm{a}}$ & $95.0^{\mathrm{b}}$ & $96.6^{\mathrm{a}}$ & $70.9^{\mathrm{b}}$ \\
\hline
\end{tabular}

${ }^{\mathrm{a}-\mathrm{c}}$ Means within phases in columns with different superscripts differ $(P<0.01)$.

d,e Means within phases in columns with different superscripts differ $(P<0.10)$.

${ }^{1}$ Least squares means of apparent total-tract digestibility of DM (DMD), organic matter (OMD), crude protein (CPD), ADF (ADFD), NDF (NDFD), starch (STAD), sugar (SUGD), and fat (FATD) by measurement period during the nursery phase $(0$ to $8 \mathrm{wk})$ and grower phase $(8$ to $16 \mathrm{wk})$ of the trial.

\section{Serum Parameters}

Changes in indices of calf immunity and stress are provided in Table 8 . Blood samples were collected at one day before weaning ( -1 wean; $\mathrm{d} 41$ of the study) and $3 \mathrm{~d}$ after weaning ( +3 wean; $\mathrm{d} 45$ of the study). Samples were also collected at $1 \mathrm{~d}$ before moving from individual pens to group housing ( -1 move; $d 55)$ and

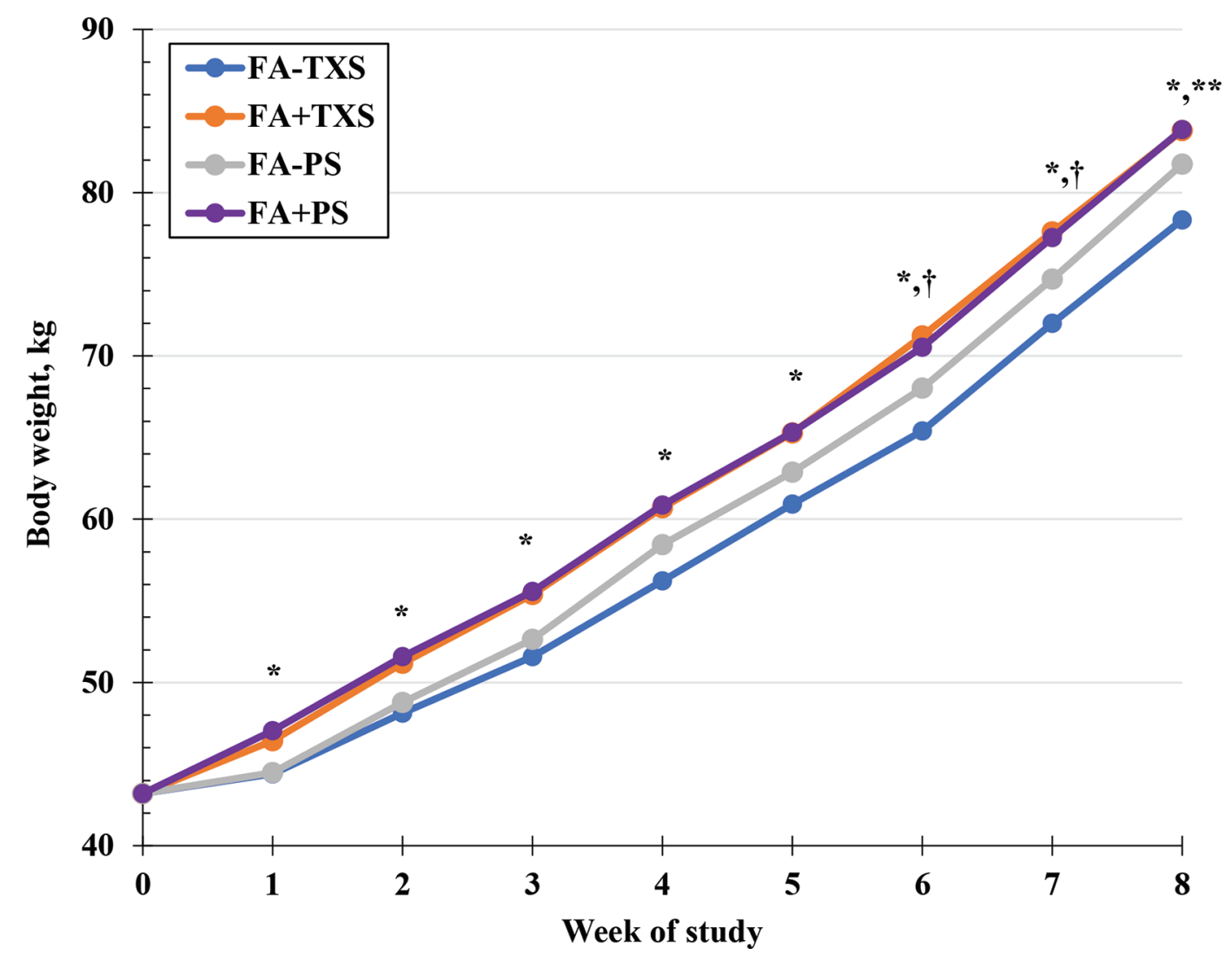

Figure 2. Least squares means of weekly BW in calves fed diets without $(\mathrm{FA}-$ ) or with $(\mathrm{FA}+)$ fatty acid blend and texturized (TXS) or pelleted (PS) calf starter. Least squares means were covariately adjusted for initial BW. SE $=1.07$. ${ }^{*}$ Within week, FA $+>$ FA,$- P<0.05$. $\nmid$ Within week, FA-PS $>$ FA-TXS, $P<0.10$. **Within week, FA-PS $>$ FA-TXS, $P<0.01$. 
Table 6. Apparent total-tract digestibility in calves fed calf starters with different physical forms and milk powder or calf starter without or with fatty acid blend during the nursery period (0 to $8 \mathrm{wk}$ )

\begin{tabular}{|c|c|c|c|c|c|c|c|c|}
\hline \multirow[b]{2}{*}{ Item } & \multicolumn{4}{|c|}{ Treatment $^{1}$} & \multirow[b]{2}{*}{ SEM } & \multicolumn{3}{|c|}{ Contrast $^{2}$} \\
\hline & $\mathrm{FA}-\mathrm{TXS}$ & $\mathrm{FA}+\mathrm{TXS}$ & $\mathrm{FA}-\mathrm{PS}$ & $\mathrm{FA}+\mathrm{PS}$ & & Form & FA & Int. \\
\hline \multicolumn{9}{|l|}{$\overline{\mathrm{Wk}} 4$} \\
\hline \multicolumn{9}{|l|}{ Digestibility, \% } \\
\hline DM & 92.1 & 94.0 & 87.5 & 94.1 & 1.99 & 0.27 & 0.05 & 0.25 \\
\hline $\mathrm{OM}$ & 92.4 & 94.2 & 87.8 & 94.2 & 1.96 & 0.26 & 0.05 & 0.26 \\
\hline Starch & 97.8 & 98.8 & 98.3 & 99.6 & 0.41 & 0.15 & 0.02 & 0.68 \\
\hline Sugar & 96.5 & 98.6 & 96.7 & 98.9 & 1.21 & 0.82 & 0.09 & 0.96 \\
\hline NDF & 9.3 & 34.6 & 19.0 & 23.0 & 7.12 & 0.89 & 0.06 & 0.16 \\
\hline $\mathrm{ADF}$ & 4.6 & 24.1 & 12.9 & 12.5 & 6.34 & 0.80 & 0.15 & 0.14 \\
\hline $\mathrm{CP}$ & 89.6 & 92.4 & 84.0 & 92.5 & 2.13 & 0.21 & 0.02 & 0.21 \\
\hline Fat & 98.4 & 98.7 & 97.6 & 98.7 & 0.43 & 0.33 & 0.10 & 0.33 \\
\hline Starter intake, $\mathrm{kg}$ & 0.15 & 0.22 & 0.28 & 0.19 & 0.053 & 0.38 & 0.76 & 0.14 \\
\hline Total intake, kg & 0.81 & 0.87 & 0.94 & 0.84 & 0.053 & 0.38 & 0.76 & 0.14 \\
\hline \multicolumn{9}{|l|}{ Wk 6} \\
\hline \multicolumn{9}{|l|}{ Digestibility, \% } \\
\hline $\mathrm{DM}$ & 89.4 & 91.7 & 86.0 & 89.2 & 1.44 & 0.06 & 0.07 & 0.79 \\
\hline $\mathrm{OM}$ & 89.7 & 92.0 & 86.2 & 89.3 & 1.45 & 0.05 & 0.08 & 0.79 \\
\hline Starch & 98.7 & 99.0 & 96.8 & 98.1 & 0.71 & 0.07 & 0.28 & 0.48 \\
\hline Sugar & 99.3 & 99.1 & 97.1 & 97.7 & 0.77 & 0.03 & 0.80 & 0.61 \\
\hline NDF & 38.5 & 60.8 & 38.4 & 44.1 & 6.56 & 0.22 & 0.05 & 0.22 \\
\hline $\mathrm{ADF}$ & 24.0 & 53.6 & 29.0 & 33.4 & 8.18 & 0.37 & 0.06 & 0.14 \\
\hline $\mathrm{CP}$ & 88.7 & 90.3 & 84.9 & 89.6 & 1.54 & 0.16 & 0.06 & 0.33 \\
\hline Fat & 97.0 & 97.4 & 96.1 & 97.0 & 0.56 & 0.27 & 0.33 & 0.65 \\
\hline Starter intake, kg & 0.49 & 0.72 & 0.67 & 0.64 & 0.114 & 0.67 & 0.39 & 0.26 \\
\hline Total intake, kg & 0.82 & 1.05 & 1.00 & 0.97 & 0.114 & 0.67 & 0.39 & 0.26 \\
\hline \multicolumn{9}{|l|}{ Wk 8} \\
\hline \multicolumn{9}{|l|}{ Digestibility, \% } \\
\hline DM & 80.9 & 83.1 & 73.4 & 76.5 & 0.49 & 0.001 & 0.001 & 0.36 \\
\hline $\mathrm{OM}$ & 81.7 & 83.9 & 74.0 & 77.0 & 0.48 & 0.001 & 0.001 & 0.42 \\
\hline Starch & 96.4 & 97.0 & 97.2 & 98.1 & 0.62 & 0.15 & 0.25 & 0.86 \\
\hline Sugar & 98.5 & 98.6 & 95.4 & 95.7 & 0.86 & 0.003 & 0.84 & 0.91 \\
\hline $\mathrm{NDF}$ & 43.2 & 52.6 & 21.2 & 28.5 & 2.47 & 0.001 & 0.004 & 0.66 \\
\hline $\mathrm{ADF}$ & 34.4 & 48.4 & 17.5 & 24.8 & 3.99 & 0.001 & 0.02 & 0.41 \\
\hline $\mathrm{CP}$ & 79.7 & 81.0 & 67.8 & 70.1 & 1.32 & 0.001 & 0.19 & 0.73 \\
\hline Fat & 87.2 & 85.7 & 82.9 & 85.9 & 2.19 & 0.37 & 0.73 & 0.32 \\
\hline Starter intake, $\mathrm{kg}$ & 1.68 & 1.88 & 1.88 & 1.92 & 0.135 & 0.41 & 0.38 & 0.54 \\
\hline
\end{tabular}

${ }^{1}$ Treatment: whole milk powder without $(\mathrm{FA}-)$ or with $(\mathrm{FA}+)$ fatty acid blend, texturized starter (TXS), or pelleted starter (PS). From d 43 to 56, starters were formulated without (FA-) or with (FA+) fatty acid blend. ${ }^{2}$ Contrast: effect of calf starter form (pelleted vs. texturized; form), inclusion of fatty acid blend (FA), and interaction (Int.).

$6 \mathrm{~d}$ postmoving (+6 move; $\mathrm{d} 62$ ). Changes from pre- to postevent were defined as "wean" and "move," respectively.

Serum bactericidal assay was greater (indicating greater immune competence) in calves fed $\mathrm{FA}+$ at -1 Wean. By +3 wean, there were no differences among treatments. Thus, removal of FA from the milk (before weaning, FA was added to liquid diet only) resulted in a greater depression in SBA with weaning $(P<0.03)$. There was also a CS form $\times$ FA interaction at -1 move for SBA. Calves fed FA-TXS had lower SBA than other calves. However, by +6 move, there were no differences in SBA (Table 8). Thus, the change associated with moving was greater for FA-TXS compared with FA+TXS.

Serum haptoglobin was higher in calves fed TXS at +3 wean. Increase in haptoglobin due to weaning tended to be greater in calves fed TXS, also. Calves fed TXS tended to have lower haptoglobin concentration compared with calves fed PS at +6 move.

Treatment, age, and management had few effects on serum cortisol. Calves fed TXS had lower serum cortisol at -1 move compared with calves fed FA+PS. Other comparisons were not significant.

\section{DISCUSSION}

\section{Animal Performance}

Calves fed FA+ grew faster and were more efficient than calves fed FA - throughout the experiment. These observations are consistent with other research with fatty acids such as butyrate alone fed to pre-weaned calves (Guilloteau et al., 2004, 2009b; Kato et al., 2011) 
or in combination in proprietary FA fed to pre-weaned and weaned calves to 4 mo of age (Hill et al., 2011a,b; Esselburn et al., 2013). Weekly BW (Figure 2) differed between $\mathrm{FA}$ - and $\mathrm{FA}+$ by 1 wk of the trial, indicating the effect of FA began shortly after inclusion in the diet.

Presumably, FA added to milk would bypass the rumen by closure of the esophageal groove; therefore, increased TTD of DM, OM, starch, and CP at 4 wk and NDF, ADF, and $\mathrm{CP}$ was likely mediated via more rapid development of intestinal digestive mechanisms, changes in microbial flora or insulin sensitivity, as suggested by others (Guilloteau et al., 2009b, 2010; Kato et al., 2011). Górka et al. (2014) reported differential responses to addition of sodium butyrate to milk replacer or CS. These authors suggested that sodium butyrate added to milk could indirectly stimulate rumen development, perhaps by increased concentrations of glucose and AA in the circulation. On the other hand, not all research with butyrate has shown positive responses (e.g., Wanat et al., 2015) and negative effects of butyrate on palatability of CS have been implicated. However, we found no negative effects of FA on intake or palatability.

Physical form of CS with similar nutrient content had no effect on intake, ADG, change in hip width, or change in BCS during the nursery or grower phases of the trial. Calves fed TXS had more days with fluid feces $(\geq 2.5$ fecal score) during the nursery phase, particularly during the last $4 \mathrm{wk}$ of the trial when CS intake increased around weaning (Figure 3). Increased fecal fluidity could be a result of greater intestinal starch fermentation, which reduced solids concentration of feces (Gressley et al., 2011), though not to the extent

Table 7. Apparent total-tract digestibility in calves fed calf starters with different physical forms and milk powder or calf starter without or with fatty acid blend during the grower period (8 to $16 \mathrm{wk}$ )

\begin{tabular}{|c|c|c|c|c|c|c|c|c|}
\hline \multirow[b]{2}{*}{ Item } & \multicolumn{4}{|c|}{ Treatment $^{1}$} & \multirow[b]{2}{*}{ SEM } & \multicolumn{3}{|c|}{ Contrast $^{2}$} \\
\hline & $\mathrm{FA}-\mathrm{TXS}$ & $\mathrm{FA}+\mathrm{TXS}$ & $\mathrm{FA}-\mathrm{PS}$ & $\mathrm{FA}+\mathrm{PS}$ & & Form & FA & Int. \\
\hline \multicolumn{9}{|l|}{ Wk 10} \\
\hline \multicolumn{9}{|l|}{ Digestibility, \% } \\
\hline DM & 76.4 & 78.7 & 77.9 & 80.1 & 0.52 & 0.02 & 0.003 & 0.96 \\
\hline $\mathrm{OM}$ & 78.2 & 79.9 & 78.6 & 81.1 & 0.54 & 0.17 & 0.004 & 0.48 \\
\hline Starch & 96.6 & 96.5 & 97.2 & 98.8 & 0.87 & 0.14 & 0.43 & 0.36 \\
\hline Sugar & $98.3^{\mathrm{b}}$ & $97.3^{\mathrm{b}}$ & $92.6^{\mathrm{a}}$ & $97.6^{\mathrm{b}}$ & 1.02 & 0.03 & 0.09 & 0.02 \\
\hline NDF & 35.3 & 38.1 & 36.1 & 42.9 & 3.35 & 0.42 & 0.19 & 0.57 \\
\hline $\mathrm{ADF}$ & 23.2 & 25.2 & 24.4 & 29.2 & 4.05 & 0.55 & 0.42 & 0.74 \\
\hline $\mathrm{CP}$ & 77.0 & 79.8 & 78.3 & 80.0 & 1.36 & 0.61 & 0.13 & 0.68 \\
\hline Fat & 71.8 & 80.6 & 83.2 & 82.2 & 4.57 & 0.19 & 0.42 & 0.32 \\
\hline Starter intake, $\mathrm{kg}$ & 3.2 & 3.0 & 3.0 & 3.4 & 0.16 & 0.61 & 0.61 & 0.11 \\
\hline \multicolumn{9}{|l|}{ Wk 13} \\
\hline \multicolumn{9}{|l|}{ Digestibility, \% } \\
\hline DM & 75.8 & 77.7 & 79.3 & 81.8 & 0.50 & 0.001 & 0.003 & 0.52 \\
\hline $\mathrm{OM}$ & 77.1 & 78.9 & 80.8 & 83.7 & 0.82 & 0.001 & 0.02 & 0.54 \\
\hline Starch & 94.6 & 95.9 & 98.4 & 98.4 & 0.58 & 0.001 & 0.29 & 0.27 \\
\hline Sugar & $98.2^{\mathrm{b}}$ & $96.6^{\mathrm{a}}$ & $97.9^{\mathrm{b}}$ & $98.6^{\mathrm{b}}$ & 0.51 & 0.15 & 0.41 & 0.05 \\
\hline NDF & 39.1 & 43.9 & 47.2 & 50.3 & 1.42 & 0.001 & 0.02 & 0.57 \\
\hline $\mathrm{ADF}$ & 26.7 & 30.2 & 30.7 & 32.5 & 4.49 & 0.50 & 0.58 & 0.85 \\
\hline $\mathrm{CP}$ & 77.9 & 79.2 & 78.9 & 82.0 & 1.35 & 0.20 & 0.14 & 0.55 \\
\hline Fat & 73.0 & 68.7 & 79.6 & 74.5 & 2.33 & 0.03 & 0.07 & 0.86 \\
\hline Starter intake, kg & 4.1 & 3.8 & 3.6 & 4.1 & 0.24 & 0.69 & 0.55 & 0.13 \\
\hline \multicolumn{9}{|l|}{ Wk 16} \\
\hline \multicolumn{9}{|l|}{ Digestibility, \% } \\
\hline $\mathrm{DM}$ & 75.5 & 77.4 & 74.6 & 77.1 & 0.49 & 0.26 & 0.002 & 0.60 \\
\hline $\mathrm{OM}$ & 76.9 & 78.7 & 75.5 & 78.1 & 0.51 & 0.10 & 0.002 & 0.42 \\
\hline Starch & 93.4 & 92.1 & 97.5 & 97.2 & 0.99 & 0.002 & 0.47 & 0.63 \\
\hline Sugar & 96.9 & 97.3 & 94.9 & 97.2 & 0.61 & 0.12 & 0.06 & 0.16 \\
\hline $\mathrm{NDF}$ & 38.7 & 43.3 & 30.2 & 41.0 & 3.27 & 0.13 & 0.05 & 0.37 \\
\hline $\mathrm{ADF}$ & 30.9 & 40.8 & 18.9 & 32.7 & 3.47 & 0.02 & 0.009 & 0.59 \\
\hline $\mathrm{CP}$ & 76.8 & 79.6 & 74.4 & 77.1 & 0.99 & 0.04 & 0.02 & 0.95 \\
\hline Fat & 67.4 & 70.1 & 75.1 & 71.1 & 3.33 & 0.23 & 0.85 & 0.34 \\
\hline Starter intake, kg & 5.1 & 4.9 & 5.0 & 5.7 & 0.22 & 0.17 & 0.25 & 0.05 \\
\hline
\end{tabular}


of causing diarrhea (fecal score $\geq 3$ ). We did not measure fecal scores during the grower phase of the trial; therefore, it is unknown if fluid feces caused by TXS continued following inclusion of $5 \%$ hay in the diet. Increased fecal starch and lower TTSD is consistent with the theory that greater amounts of starch were available for fermentation in the large intestine of calves fed TXS; however, TXS diets also contained a different form of NDF. The PS contained $20 \%$ wheat middlings, which replaced whole oats in TXS. Digestion of NDF in calves fed PS was generally lower than calves fed the TXS. Additional NDF and ADF in the feces could potentially absorb moisture, resulting in less fluid feces compared with calves fed TXS. It should be noted that fecal score $\geq 2.5$ was not necessarily indicative of clinical acidosis, as evidenced by diarrhea, epithelial damage, and presence of mucin casts in feces (Gressley et al., 2011), but rather a change in fecal composition indicative of a more moderate metabolic condition.

\section{Nutrient Digestion}

Digestion of nutrients changed with age. During the nursery phase, digestion of DM, OM, CP, and fat declined, likely due to increasing proportion of total DMI from CS. Similar results from our laboratory have been reported (Hill et al., 2016a; Quigley et al., 2018). However, digestion of $\mathrm{ADF}$ and NDF increased from
4 to $6 \mathrm{wk}$, which is consistent with developing rumen function. During the grower phase of the trial, TTD of DM, OM, starch, and fat generally declined from 10 to 16 wk of age, which may be related to increasing DMI and rate of passage.

Feeding FA+ during the nursery and grower phases of the trial increased or tended to increase digestion of most nutrients measured. This observation is consistent with previous studies with individual fatty acids (Guilloteau et al., 2010) or FA (Hill et al., 2016a). Guilloteau et al. (2010) reported that improved digestion with inclusion of butyrate in the diet was likely caused by increased pancreatic secretion. Kato et al. (2011) reported that addition of sodium butyrate to milk increased rumen papillary development, and altered plasma growth hormone and insulin concentrations in response to milk feeding. Feeding TXS increased or tended to increase digestion of DM, OM, starch, and sugar at 6 wk and DM, OM, sugar, NDF, ADF, and $\mathrm{CP}$ at 8 wk. During the grower phase, starch, sugar, and fat digestion generally declined with advancing age when TXS was fed.

\section{Fecal Starch and Starch Digestion}

Concentration of starch in feces of calves fed TXS was consistently higher than feces from calves fed PS from 8 wk of the study (Figure 4). Differences in fecal

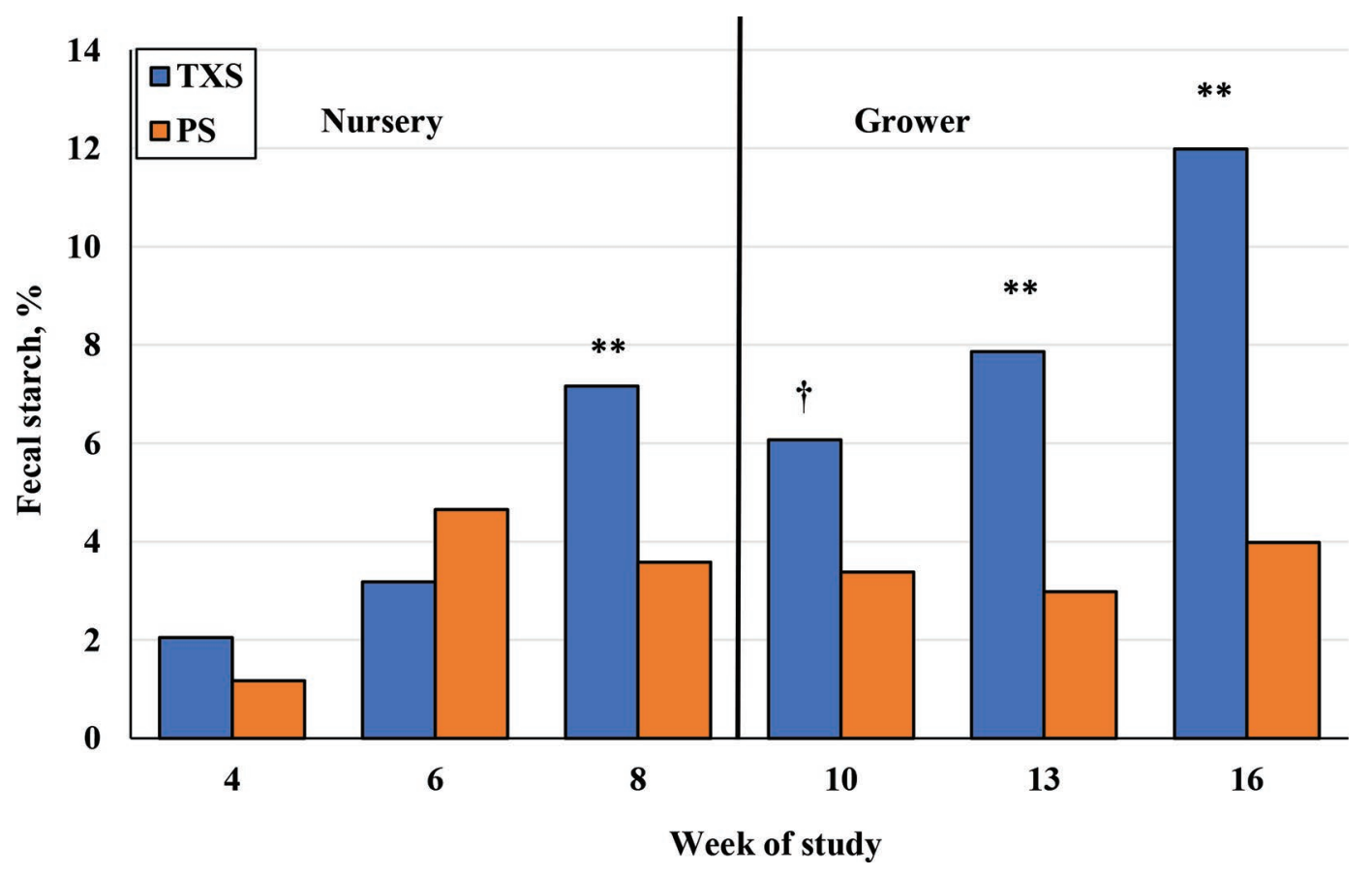

Figure 4. Least squares means of fecal starch in calves fed textured (TXS) or pelleted (PS) calf starters during the nursery phase (wk 4 to $8 ; \mathrm{n}=20$ observations per week) and grower phase (wk 10 to $13 ; \mathrm{n}=12$ observations per week) of the trial. Standard errors for nursery and grower means were 0.72 and $1.02 \%$, respectively. ${ }^{* *} P<0.01 . \dagger P<0.10$. 


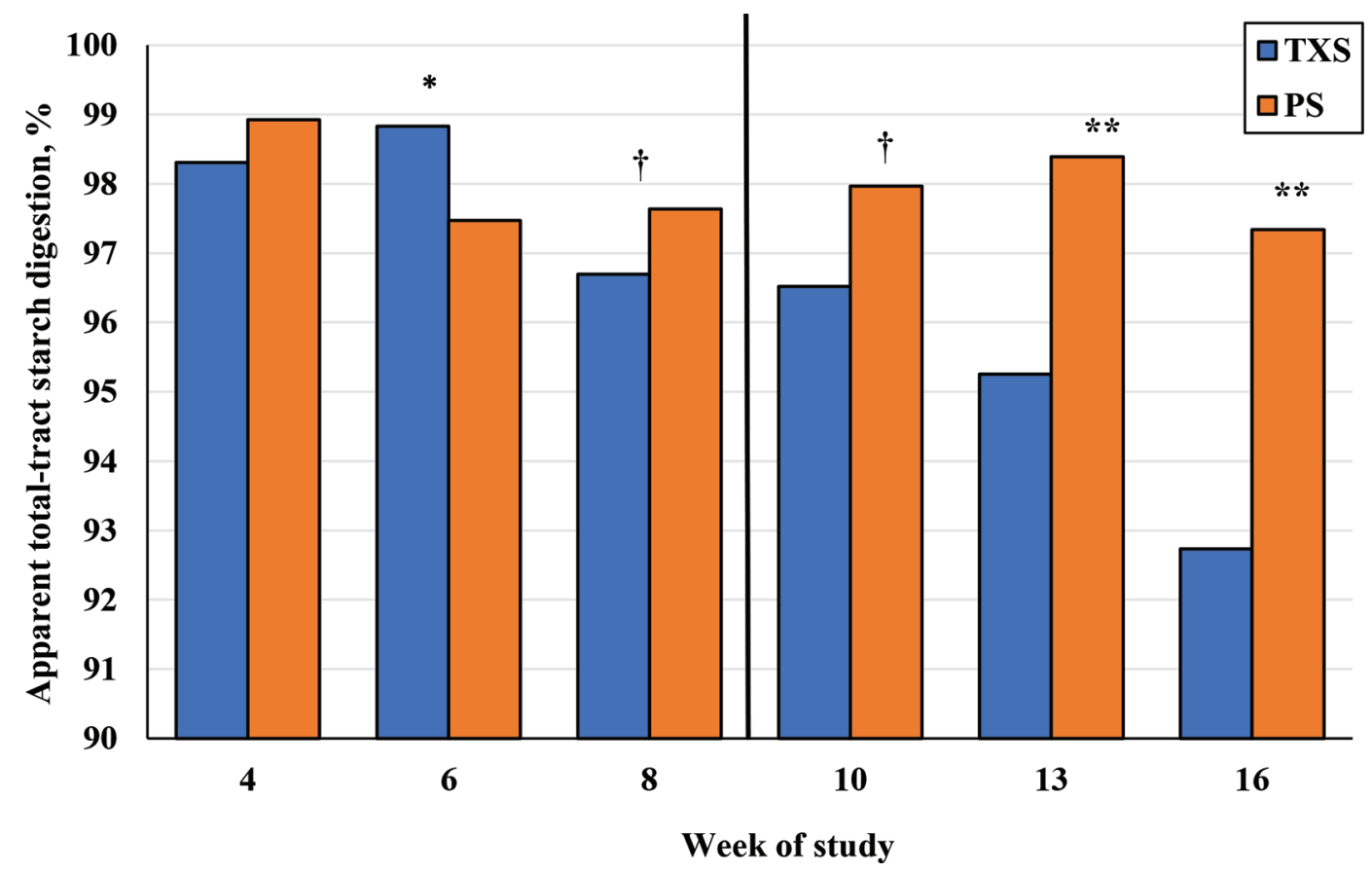

Figure 5. Least squares means of apparent total-tract starch digestion in calves fed textured (TXS) or pelleted (PS) calf starters during the nursery (wk 4 to $8 ; \mathrm{n}=20$ observations per week) and grower (wk 10 to $13 ; \mathrm{n}=12$ observations per week) phases of the trial. Standard errors for nursery and grower means were 0.42 and $0.58 \%$, respectively. ${ }^{*} P<0.05 . \dagger P<0.10 .{ }^{* *} P<0.01$.

starch were independent of differences in DMI, which did not vary by treatment during the study. Similarly, apparent TTSD declined with increasing age (and DM and starch intake) in calves fed TXS, whereas starch digestion was unaffected by week in calves fed PS (Figure 5). Differences in starch digestion between PS and TXS occurred at 13 and 16 wk of age. Starch digestion of the TXS was $95 \%$ at $10 \mathrm{wk}$ and $93 \%$ at $16 \mathrm{wk}$ compared with 98 and $97 \%$, respectively, for PS. These data suggest that differences in starter form, possibly inclusion of whole grains in TXS diets, could reduce starch digestion via passage of whole grains in TXS (which contained most of the starch in TXS diets). Further, gelatinization of a greater portion of starch due to pelleting PS may also contribute to increased starch digestion in calf starters (Mojahedi et al., 2018). Increasing DMI and concomitant increased rate of passage could be responsible for observed changes in total TTSD and fecal starch concentrations. However, differences in starch digestion between starter form did not change ADG or structural growth.

Linear relationships between TTSD and fecal starch concentration are consistent with observations in adult cattle (Fredin et al., 2014; Owens et al., 2016). Previously, we reported a poor relationship between starch digestion and fecal starch concentration in 3- and 6-wkold pre-weaned calves (Dennis et al., 2017), but a linear relationship between starch digestion and fecal starch after weaning. The linear regression equation of TTSD versus fecal starch in calves at $8 \mathrm{wk}$ in Dennis et al. $(2017)$ was TTSD $(\%)=99.683-0.618 \times$ fecal starch $(\%) ; \mathrm{R}^{2}=0.86$. Calves in the study by Dennis et al. (2017) were fed high starch textured CS similar to the TXS treatment in our study. However, some estimates were made at $3 \mathrm{wk}$ of age in calves fed $0.66 \mathrm{~kg}$ of milk replacer/d and up to $1.31 \mathrm{~kg}$ of milk replacer/d; the higher rate delayed and reduced starter intake. Linear regression of TTSD versus fecal starch in calves fed TXS during the nursery phase $(4,6$, and 8 wk) of our study was TTSD $(\%)=99.639-0.411 \times$ fecal starch $(\%) ; \mathrm{R}^{2}=0.79$. The relationship in the grower $(10,13$, and $16 \mathrm{wk})$ had less variation $\left(\mathrm{R}^{2}=0.98\right)$.

Relationship between fecal starch and TTSD in calves in our study and that of Dennis et al. (2017) were similar to reports in feedlot cattle (Owens et al., 2016) and differed from data in dairy cattle (Fredin et al., 2014). Differences to the relationships reported were likely due to differences in ration type, amount, and type of starch fed, degree of grain processing, and gastrointestinal maturation. For example, Corona et al. (2005) reported that fecal starch decreased with increasing extent of processing of corn grain fed to feedlot cattle. Fecal starch decreased from $25.9 \%$ in diets containing whole corn to $1.8 \%$ in steam-flaked corn in 
the study by Corona et al. (2005). Our calves and those of Dennis et al. (2017) were fed diets consisting of 95 or $100 \%$ concentrate containing $>38 \%$ starch during the first 2 mo of each study and $>35 \%$ starch from 2 to 4 mo of age. Most of the starch in our textured diets and those fed by Dennis et al. (2017) was provided by whole corn and whole oats.

\section{Serum Parameters}

Immunocompetence measured by SBA was higher in calves fed FA + in milk at -1 wean (Table 8). According to Hulbert and Moisá (2016), acute stressors such as weaning may influence an animal's immunocompetence and resilience. This influence may explain the reason
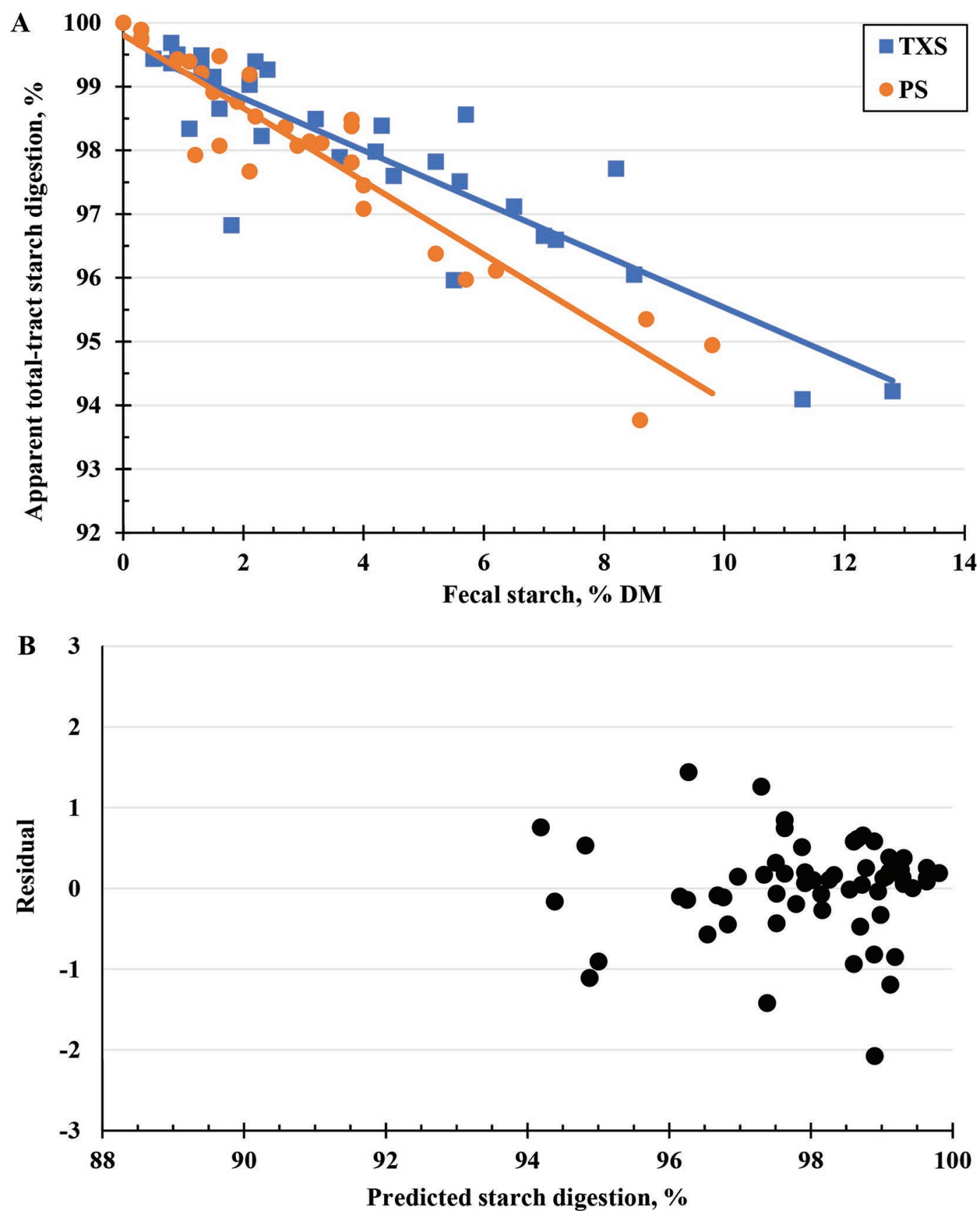

Figure 6. (A) Regression of apparent total-tract starch digestion (TTSD) on fecal starch concentration in calves fed textured (TXS) or pelleted (PS) calf starters during the nursery phase of the trial (wk 4 to $8 ; \mathrm{n}=20$ observations per week). Regression equation was TTSD $=$ $99.81( \pm 0.181)-0.57( \pm 0.045) \times$ fecal starch, \% DM $-0.17( \pm 0.261) \times$ form $(0=\mathrm{PS}, 1=\mathrm{TXS})+0.16( \pm 0.058) \times($ fecal starch $\times$ form $)$; root mean square error $=0.624 ; R^{2}=0.84$. (B) Residual plot: $\mathrm{Y}=0.00( \pm 5.64)+0.00( \pm 0.06) \times$ predicted TTSD; root mean square error $=$ $0.613 ; \mathrm{R}^{2}=0.00$. 
why, by +3 wean, there were no differences among treatments. Removal of FA from milk (before weaning, FA was added to liquid diet only) resulted in a greater depression in SBA with weaning $(P<0.03)$. Although $\mathrm{FA}+$ calf starter contained the FA, intake of $\mathrm{FA}$ was lower from CS at the week of weaning compared with intake from milk powder. Fatty acids modulate immune responses by providing substrates for either pro- or anti-inflammatory factors. For example, arachidonic acid is a precursor to prostaglandins, leukotrienes, and
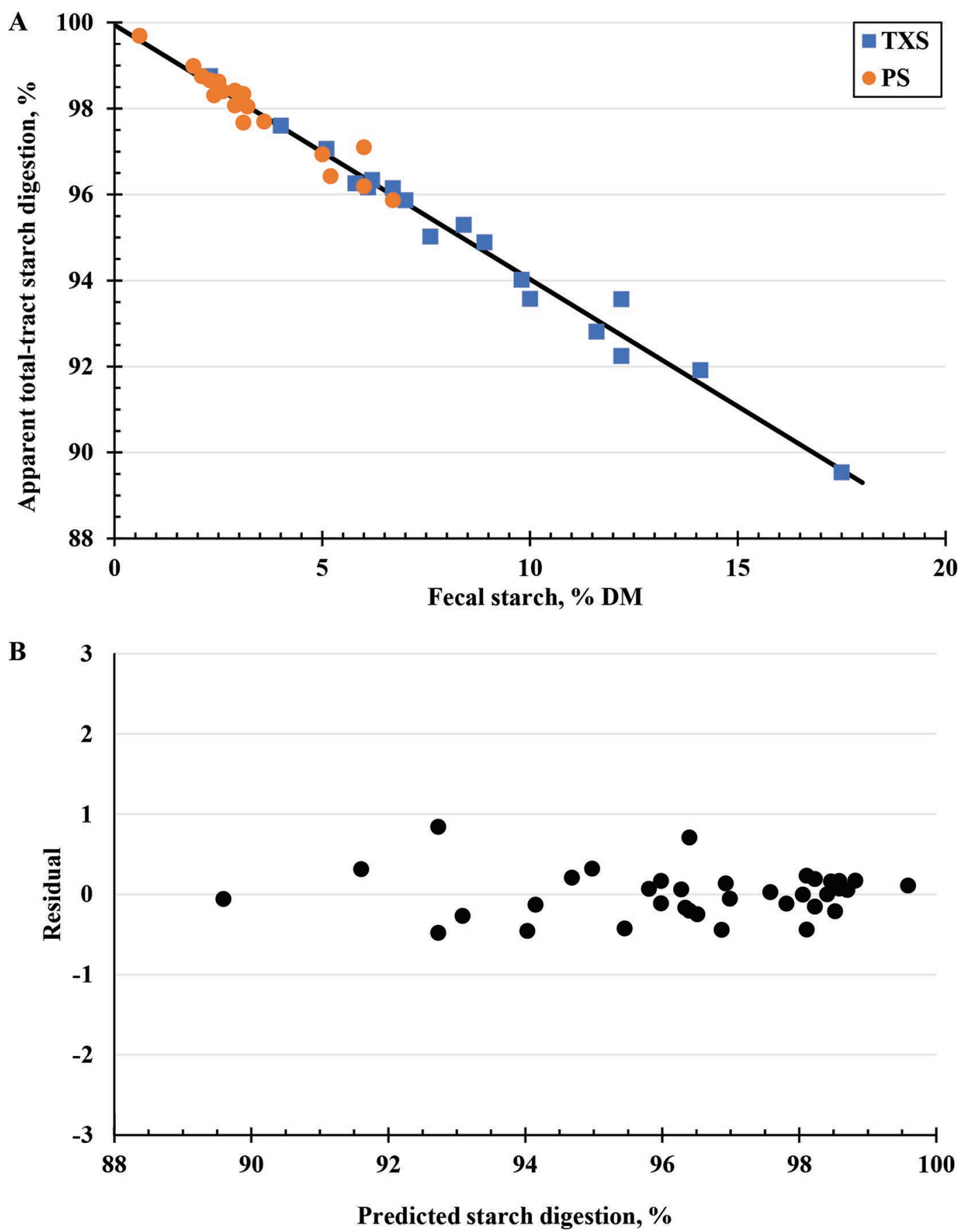

Figure 7. (A) Regression of apparent total-tract starch digestion (TTSD) on fecal starch concentration in calves fed textured (TXS) or pelleted (PS) calf starters during the grower phase of the trial (wk 10 to $16 ; \mathrm{n}=12$ observations per week). Regression equation was TTSD $=$ $99.94( \pm 0.092)-0.59( \pm 0.013) \times$ fecal starch; root mean square error $=0.298 ; R^{2}=0.98 .(B)$ Residual plot: $\mathrm{Y}=0.00( \pm 2.10)+0.00( \pm 0.022)$ $\times$ predicted TTSD; root mean square error $=0.298 ; \mathrm{R}^{2}=0.00$. 
related compounds (Calder, 2001). Our data suggest that weaning reduced intake of the FA, which may have reduced SBA at weaning.

At -1 move (d 55 of the study), SBA was lower in calves fed FA-TXS. However, $6 \mathrm{~d}$ after comingling and introduction of a TMR containing $95 \%$ calf starter + $5 \%$ hay, there was no difference in SBA activity. We speculate that calves fed TXS experienced metabolic stress due to intestinal fermentation of carbohydrate from whole grains bypassing ruminal fermentation. Addition of FA+ to FA+TXS treatment could have ameliorated the effect of textured feed on SBA, and thus, only calves on FA-TXS treatment exhibited reduced SBA. Further, the increase in SBA from +3 wean $(45$ $\mathrm{d}$ of the study) to -1 move $(55 \mathrm{~d})$ was significant $(P<$ $0.05)$ for all calves except those fed FA-TXS, supporting this hypothesis. A lack of effect at +6 move could be due to the inclusion of $5 \%$ hay in the diet, which could improve rumen $\mathrm{pH}$ and rumen fermentation, alter rate of passage, and reduce effects of intestinal fermentation. However, additional data are needed to evaluate these hypotheses.

Calves fed FA+ had higher concentrations of SBA, suggesting that modifying the fatty acid profile of the diet can improve immune response in young calves. Others (Hill et al., 2011b; Esselburn et al., 2013) have also reported improve indices of immunity in young calves fed a commercial product containing a similar FA.

Haptoglobin is an acute phase protein that is used as an index of stress and inflammation in animals, including cattle and calves (Plaizier et al., 2008, 2012). Concentrations of serum haptoglobin ranged from 27 to $92 \mu \mathrm{g} / \mathrm{mL}$ (Table 8) in our study. Before weaning ( -1 wean), concentrations were generally low and were unaffected by treatment. These data indicate that calves were not experiencing infections caused by pathogens, or psychological or metabolic stress. However by $3 \mathrm{~d}$ postweaning, calves fed TXS had higher haptoglobin concentrations, whereas concentration did not differ from zero in calves fed PS.

Murray et al. (2014) reported that haptoglobin was related to morbidity and mortality in newborn calves to 4 mo of age. They reported a relationship between serum haptoglobin and rectal temperatures and depression in calves. They also proposed that a cut-point of $0.13 \mathrm{~g} / \mathrm{L}$ of haptoglobin $(130 \mu \mathrm{g} / \mathrm{mL})$ was predictive of increased risk of morbidity and mortality in calves. The number of calves with haptoglobin $>130 \mu \mathrm{g} / \mathrm{mL}$ at -1 wean $(\mathrm{n}=2)$ and +3 wean $(\mathrm{n}=4)$ and -1 move $(\mathrm{n}=$ $2)$ and +6 move $(n=1)$ suggests that levels of stress in our calves was insufficient to increase predisposition to disease. Others (Godson et al., 1996; Deignan et al., 2000; Murray et al., 2018) have also reported that hap-

Table 8. Least squares means of serum bactericidal activity (SBA), haptoglobin, and cortisol taken at -1 and $+3 \mathrm{~d}$ after weaning (wean) and -1 and $+6 \mathrm{~d}$ after moving (move) from individual pens to group pens

\begin{tabular}{|c|c|c|c|c|c|c|c|c|}
\hline \multirow[b]{2}{*}{ Item } & \multicolumn{4}{|c|}{ Treatment $^{1}$} & \multirow[b]{2}{*}{$\mathrm{SE}$} & \multicolumn{3}{|c|}{ Contrast $^{2}$} \\
\hline & $\mathrm{FA}-\mathrm{TXS}$ & $\mathrm{FA}+\mathrm{TXS}$ & $\mathrm{FA}-\mathrm{PS}$ & $\mathrm{FA}+\mathrm{PS}$ & & Form & $\mathrm{FA}$ & Int. \\
\hline \multicolumn{9}{|l|}{$\mathrm{SBA}^{3}$} \\
\hline-1 wean & 34.0 & 60.0 & 35.8 & 54.9 & 6.65 & 0.80 & 0.001 & 0.59 \\
\hline+3 wean & 25.2 & 35.0 & 27.4 & 27.2 & 7.11 & 0.68 & 0.48 & 0.46 \\
\hline Wean & -8.8 & -25.0 & -8.4 & -27.8 & 8.15 & 0.88 & 0.03 & 0.84 \\
\hline-1 move & $29.4^{\mathrm{a}}$ & $54.7^{\mathrm{b}}$ & $48.4^{\mathrm{b}}$ & $44.2^{\mathrm{b}}$ & 6.64 & 0.51 & 0.11 & 0.03 \\
\hline \multicolumn{9}{|c|}{ Haptoglobin, $\mu \mathrm{g} / \mathrm{mL}$} \\
\hline-1 wean & 50.4 & 40.0 & 30.6 & 56.6 & 11.81 & 0.89 & 0.50 & 0.12 \\
\hline+3 wean & 91.5 & 65.4 & 29.5 & 50.4 & 17.94 & 0.03 & 0.88 & 0.18 \\
\hline Wean & 37.5 & 25.4 & -1.1 & -6.2 & 19.59 & 0.07 & 0.65 & 0.86 \\
\hline-1 move & 50.1 & 57.3 & 36.2 & 27.4 & 14.92 & 0.13 & 0.95 & 0.58 \\
\hline+6 move & $43.2^{\mathrm{ab}}$ & $28.2^{\mathrm{a}}$ & $32.0^{\mathrm{ab}}$ & $50.6^{\mathrm{b}}$ & 8.33 & 0.49 & 0.82 & 0.05 \\
\hline Move & -7.0 & -29.1 & -4.2 & 23.2 & 15.91 & 0.08 & 0.86 & 0.11 \\
\hline+6 move & 21.5 & 21.6 & 21.9 & 24.6 & 2.59 & 0.50 & 0.58 & 0.61 \\
\hline Move & -0.1 & 8.2 & 5.3 & 0.2 & 4.58 & 0.76 & 0.71 & 0.12 \\
\hline
\end{tabular}

\footnotetext{
${ }^{\mathrm{a}, \mathrm{b}}$ Least squares means within a row with a different superscript differ, $P<0.05$.

${ }^{1}$ Treatment: calf starter without $(\mathrm{FA}-)$ or with $(\mathrm{FA}+)$ fatty acid blend, texturized starter (TXS), or pelleted starter (PS).

${ }^{2}$ Contrast: effect of calf starter form (pelleted vs. texturized; form), inclusion of fatty acid blend (FA), and the interaction (Int.).

$3 \%$ eliminated by serum.
} 
toglobin may be related to calf morbidity or mortality. Obeidat et al. (2013) reported that plane of nutrition had no effect on blood haptoglobin concentration when measured from 3 to $162 \mathrm{~d}$ of age.

Feeding TXS tended to increase haptoglobin concentration in response to weaning at $6 \mathrm{wk}$. There are several possibilities for this observation. Calf starter intake increased from $0.6 \mathrm{~kg} / \mathrm{d}$ during wk 5 to 1.3 $\mathrm{kg} / \mathrm{d}$ during wk 6 (Figure 1). Rapid increase in consumption during the week of weaning, coupled with presence of whole grains in TXS, could have provided greater fermentable substrate for intestinal fermentation, thereby contributing to increased production of bacterial lipopolysaccharide and subsequent production of haptoglobin (Plaizier et al., 2008; Li et al., 2012). Further, if intestinal starch digestion was limited due to limited pancreatic amylase production, additional substrate would be available for fermentation in the small or large intestine. Whole oats must be chewed to make the starch available to rumen microorganisms (Suarez-Mena et al., 2015), whereas wheat starch in the pelleted CS would be rapidly available in the rumen. Processing of grains increases availability of starch in the rumen (Owens et al., 2016); thus, a greater proportion of carbohydrate in whole grains of TXS likely escaped ruminal fermentation and reached the intestines. Increased number of days that calves had fluid feces from 5 wk of age when calves were fed TXS (Figure 3) is consistent with the hypothesis that TXS contributed to a level of hind-gut fermentation in these calves. It should be noted that the increased fecal fluidity was mild and not indicative of acute acidosis.

There were no effects of treatment, weaning, or moving calves on concentrations of serum cortisol, except at -1 move, when calves fed FA+TXS had lower cortisol concentrations than calves fed FA+PS. Serum cortisol concentrations were unaffected by FA or form of CS. This is consistent with other reports with addition of butyrate to milk replacer (Nazari et al., 2012; Frieten et al., 2017). Existing literature on the effects of stressors on circulating cortisol concentrations in young calves is conflicting. For example, Kim et al. (2011) reported that weaning increased cortisol, acute phase proteins, and pro-inflammatory cytokine concentrations at 5 $\mathrm{d}$ postweaning. However, it should be noted that, in addition to weaning on $\mathrm{d} 42$, calves were also moved from individual to group pens at the time of weaning (Kim et al., 2011). Therefore, it is not clear whether increased cortisol concentration was due to removal of milk, comingling, or handling during the process of moving. Loberg et al. (2008) reported that simultaneous weaning and separation from suckler cows resulted in increased salivary cortisol, whereas separation $2 \mathrm{wk}$ after weaning had no effect on salivary cortisol levels. Hulbert et al. (2011) also reported that cortisol concentrations did not differ between calves weaned at 24 versus $45 \mathrm{~d}$ of age, though calves weaned at $45 \mathrm{~d}$ had greater plasma cortisol concentrations at $3 \mathrm{~d}$ after they were weaned. This may have been due to abrupt versus gradual weaning for calves weaned at $24 \mathrm{~d}$.

\section{CONCLUSIONS}

Different forms of CS and inclusion of a FA in milk and CS influenced growth, digestion, and serum indices of stress and immunity in calves to 4 mo of age. Feeding TXS versus PS with similar nutrient profiles had no effect on intake, growth, or feed efficiency to 4 mo of age. However, calves fed TXS had more days with fluid feces wk 5, 6, and 7 around weaning, suggesting potential hind gut fermentation. Total-tract digestion of nutrients changed with advancing age. Digestion of $\mathrm{DM}, \mathrm{OM}, \mathrm{CP}$, starch, and fat generally declined from 4 to 8 wk of age, whereas digestion of ADF and NDF increased to 6 and 8 wk, respectively. Feeding TXS increased TTD of DM, OM, sugar, NDF, ADF, and CP compared with PS at 8 wk. However, TTD of starch was lower at 13 and 16 wk when calves were fed TXS. Feeding FA increased animal performance, digestion, and efficiency, and improved indices of calf health.

\section{ACKNOWLEDGMENTS}

The authors acknowledge the assistance of R. Schlotterbeck and farm staff at the Nurture Research Center for animal care and sample collection. This research was wholly funded by Provimi North America, a division of Cargill Animal Nutrition (Brookville, OH). Additional analyses and manuscript preparation by L. E. Hulbert were funded through Kansas State University HA (Hatch Act of 1887) distributions representing the USDA-National Institute of Food and Agriculture Multistate Project W-3173 (Impacts of Stress Factors on Performance, Health, and Well-Being of Farm Animals).

\section{REFERENCES}

AOAC International. 2016. Official Methods of Analysis. Vol. I. 20th ed. AOAC International, Arlington, VA.

Bach, A., A. Gimenez, J. L. Juaristi, and J. Ahedo. 2007. Effects of physical form of a starter for dairy replacement calves on feed intake and performance. J. Dairy Sci. 90:3028-3033. https://doi .org/10.3168/jds.2006-761.

Bouchard, R., G. J. Brisson, and J. P. Julien. 1973. Nutritive value of bacterial sludge and whey powders for protein in calf milk replacers and on chromic oxide as indicator of digestibility. J. Dairy Sci. 56:1445-1449. https://doi.org/10.3168/jds.S0022-0302(73)85381 $-0$. 
Calder, P. C. 2001. Polyunsaturated fatty acids, inflammation, and immunity. Lipids 36:1007-1024. https://doi.org/10.1007/s11745 -001-0812-7.

Ceciliani, F., J. J. Ceron, P. D. Eckersall, and H. Sauerwein. 2012. Acute phase proteins in ruminants. J. Proteomics 75:4207-4231. https://doi.org/10.1016/j.jprot.2012.04.004.

Cooke, R. F., and J. D. Arthington. 2013. Concentrations of haptoglobin in bovine plasma determined by ELISA or a colorimetric method based on peroxidase activity. J. Anim. Physiol. Anim. Nutr. (Berl.) 97:531-536. https://doi.org/10.1111/j.1439-0396 .2012.01298.x.

Corona, L., S. Rodriguez, R. A. Ware, and R. A. Zinn. 2005. Comparative effects of whole, ground, dry-rolled, and steam flaked corn on digestion and growth performance in feedlot cattle. Prof. Anim. Sci. 21:200-206. https://doi.org/10.15232/S1080-7446(15)31203-1.

Coverdale, J. A., H. D. Tyler, J. D. Quigley III, and J. A. Brumm. 2004. Effect of various levels of forage and form of diet on rumen development and growth in calves. J. Dairy Sci. 87:2554-2562. https://doi.org/10.3168/jds.S0022-0302(04)73380-9.

Crokaert, F., M. Lismonst, M. V. D. Linden, and E. Yourassowsky. 1988. Determination of serum bactericidal activity against Escherichia coli by an automated photometric method. J. Clin. Microbiol. 26:2069-2076.

Danscher, A. M., M. B. Thoefner, P. M. H. Heegaard, C. T. Ekstrøm, and S. Jacobsen. 2011. Acute phase protein response during acute ruminal acidosis in cattle. Livest. Sci. 135:62-69. https://doi.org/ 10.1016/j.livsci.2010.06.009.

Deignan, T., A. Alwan, J. Kelly, J. McNair, T. Warren, and C. O'Farrelly. 2000. Serum haptoglobin: An objective indicator of experimentally-induced Salmonella infection in calves. Res. Vet. Sci. 69:153-158. https://doi.org/10.1053/rvsc.2000.0403.

Dennis, T. S., W. Hu, F. X. Suarez-Mena, T. M. Hill, J. D. Quigley and R. L. Schlotterbeck. 2017. Short communication: Use of fecal starch concentration as an indicator of dry feed digestion in preweaned dairy calves. J. Dairy Sci. 100:6266-6271. https://doi.org/ 10.3168/jds.2016-12434.

Dennis, T. S., F. X. Suarez-Mena, T. M. Hill, J. D. Quigley, R. L. Schlotterbeck, R. N. Klopp, G. J. Lascano, and L. Hulbert. 2018. Effects of gradual and later weaning ages when feeding high milk replacer rates on growth, textured starter digestibility, and behavior in Holstein calves from 0 to 4 months of age. J. Dairy Sci. 101:9863-9875. https://doi.org/10.3168/jds.2018-15319.

Dubois, M., K. A. Gilles, J. K. Hamilton, P. A. Rebers, and F. Smith 1956. Colorimetric method for determination of sugars and related substances. Anal. Chem. 28:350-356. https://doi.org/10.1021/ ac60111a017.

Esselburn, K. M., K. M. O'Diam, T. M. Hill, H. G. Bateman II, J. M. Aldrich, R. L. Schlotterbeck, and K. M. Daniels. 2013. Intake of specific fatty acids and fat alters growth, health, and titers following vaccination in dairy calves. J. Dairy Sci. 96:5826-5835. https:/ /doi.org/10.3168/jds.2013-6608.

FASS. 2010. Guide for the Care and Use of Agricultural Animals in Agricultural Research and Teaching. 3rd ed. FASS, Champaign, IL.

Fredin, S. M., L. F. Ferraretto, M. S. Akins, P. C. Hoffman, and R. D. Shaver. 2014. Fecal starch as an indicator of total-tract starch digestibility by lactating dairy cows. J. Dairy Sci. 97:1862-1871. https://doi.org/10.3168/jds.2013-7395.

Frieten, D., C. Gerbert, C. Koch, G. Dusel, K. Eder, E. Kanitz, J. M. Weitzel, and H. M. Hammon. 2017. Ad libitum milk replacer feeding, but not butyrate supplementation, affects growth performance as well as metabolic and endocrine traits in Holstein calves. J. Dairy Sci. 100:6648-6661. https://doi.org/10.3168/jds.2017-12722.

Garcia, M., J. H. Shin, A. Schlaefli, L. F. Greco, F. P. Maunsell, W. W. Thatcher, J. E. P. Santos, and C. R. Staples. 2015. Increasing intake of essential fatty acids from milk replacer benefits performance, immune responses, and health of preweaned Holstein calves. J. Dairy Sci. 98:458-477. https://doi.org/10.3168/jds.2014 -8384 .

Godson, D. L., M. Campos, S. K. Attah-Poku, M. J. Redmond, D. M. Cordeiro, M. S. Sethi, R. J. Harland, and L. A. Babiuk. 1996.
Serum haptoglobin as an indicator of the acute phase response in bovine respiratory disease. Vet. Immunol. Immunopathol. 51:277292. https://doi.org/10.1016/0165-2427(95)05520-7.

Górka, P., Z. M. Kowalski, P. Pietrzak, A. Kotunia, W. Jagusiak, J. J. Holst, P. Guilloteau, and R. Zabielski. 2011a. Effect of method of delivery of sodium butyrate on rumen development in newborn calves. J. Dairy Sci. 94:5578-5588. https://doi.org/10.3168/jds $.2011-4166$.

Górka, P., Z. M. Kowalski, P. Pietrzak, A. Kotunia, W. Jagusiak, and R. Zabielski. 2011b. Is rumen development in newborn calves affected by different liquid feeds and small intestine development? J. Dairy Sci. 94:3002-3013. https://doi.org/10.3168/jds.2010-3499.

Górka, P. P. Pietrzak, A. Kotunia, R. Zabielski, and Z. M. Kowalski. 2014. Effect of method of delivery of sodium butyrate on maturation of the small intestine in newborn calves. J. Dairy Sci 97:1026-1035. https://doi.org/10.3168/jds.2013-7251.

Gressley, T. F., M. B. Hall, and L. E. Armentano. 2011. Ruminant Nutrition Symposium: Productivity, digestion, and health responses to hindgut acidosis in ruminants. J. Anim. Sci. 89:1120-1130. https://doi.org/10.2527/jas.2010-3460.

Guilloteau, P., V. Romé, L. Le Normand, G. Savary, and R. Zabielski 2004. Is Na-butyrate a growth factor in the preruminant calf? Preliminary results. J. Anim. Feed Sci. 13(Suppl. 1):393-396. https:/ /doi.org/10.22358/jafs/73945/2004.

Guilloteau, P., G. Savary, Y. Jaguelin-Peyrault, V. Rome, L. LeNormand, and R. Zabielski. 2010. Dietary sodium butyrate supplementation increases digestibility and pancreatic secretion in young milk-fed calves. J. Dairy Sci. 93:5842-5850. https://doi.org/10 $.3168 /$ jds.2009-2751.

Guilloteau, P., R. Zabielski, and J. W. Blum. 2009a. Gastrointestinal tract and digestion in the young ruminant: Ontogenesis, adaptations, consequences and manipulations. J. Physiol. Pharmacol. 60(Suppl. 3):37-46.

Guilloteau, P., R. Zabielski, J. C. David, J. W. Blum, J. A. Morisset, M. Biernat, J. Wolinski, D. Laubitz, and Y. Hamon. 2009b. Sodium-butyrate as a growth promoter in milk replacer formula for young calves. J. Dairy Sci. 92:1038-1049. https://doi.org/10 $.3168 /$ jds.2008-1213.

Hall, M. B. 2009. Analysis of starch, including maltooligosaccharides, in animal feeds: A comparison of methods and a method recommended for AOAC collaborative study. J. AOAC Int. 92:42-49.

Hill, T. M., H. G. Bateman II, J. M. Aldrich, and R. L. Schlotterbeck. 2009. Effects of changing the essential and functional fatty acid intake of dairy calves. J. Dairy Sci. 92:670-676. https://doi.org/10 $.3168 /$ jds.2008-1368.

Hill, T. M., H. G. Bateman II, J. M. Aldrich, and R. L. Schlotterbeck. 2010. Effect of milk replacer program on digestion of nutrients in dairy calves. J. Dairy Sci. 93:1105-1115. https://doi.org/10.3168/ jds.2009-2458.

Hill, T. M., H. G. Bateman II, J. M. Aldrich, and R. L. Schlotterbeck. 2011a. Effect of various fatty acids on dairy calf performance. Prof. Anim. Sci. 27:167-175. https://doi.org/10.15232/ S1080-7446(15)30470-8.

Hill, T. M., J. D. Quigley, H. G. Bateman II, F. X. Suarez-Mena, T. S. Dennis, and R. L. Schlotterbeck. 2016b. Effect of milk replacer program on calf performance and digestion of nutrients in dairy calves to 4 months of age. J. Dairy Sci. 99:8103-8110. https://doi .org/10.3168/jds.2016-11239.

Hill, T. M., J. D. Quigley, F. X. Suarez-Mena, H. G. Bateman II, and R. L. Schlotterbeck. 2016a. Effect of milk replacer feeding rate and functional fatty acids on dairy calf performance and digestion of nutrients. J. Dairy Sci. 99:6352-6361. https://doi.org/10.3168/jds 2015-10812.

Hill, T. M., M. J. VandeHaar, L. M. Sordillo, D. R. Catherman, H. G. Bateman II, and R. L. Schlotterbeck. 2011b. Fatty acid intake alters growth and immunity in milk-fed calves. J. Dairy Sci. 94:3936-3948. https://doi.org/10.3168/jds.2010-3935.

Hulbert, L. E., and M. A. Ballou. 2012. Innate immune responses and health of individually reared Holstein calves after placement into transition-pens 23 d after weaning. J. Dairy Res. 79:333-340. https://doi.org/10.1017/S0022029912000271. 
Hulbert, L. E., C. J. Cobb, J. A. Carroll, and M. A. Ballou. 2011. The effects of early weaning on innate immune responses of Holstein calves. J. Dairy Sci. 94:2545-2556. https://doi.org/10.3168/ jds.2010-3983.

Hulbert, L. E., and S. J. Moisá. 2016. Stress, immunity and the management of calves. J. Dairy Sci. 99:3199-3216. https://doi.org/10 $.3168 /$ jds.2015-10198.

Kadkhodaya, A., A. Riasia, M. Alikhania, M. Dehghan-Banadaky, and R. Kowsar. 2017. Effects of fat sources and dietary C18:2 to C18:3 fatty acids ratio on growth performance, ruminal fermentation and some blood components of Holstein calves. Livest. Sci. 204:71-77. https://doi.org/10.1016/j.livsci.2017.08.012.

Kato, S., K. Sato, H. Chida, S.-G. Roh, S. Ohwada, S. Sato, P. Guilloteau, and K. Katoh. 2011. Effects of Na-butyrate supplementation in milk formula on plasma concentrations of GH and insulin, and on rumen papilla development in calves. J. Endocrinol. 211:241248. https://doi.org/10.1530/JOE-11-0299.

Kertz, A. F., and H. Chester-Jones. 2004. Invited review: Guidelines for measuring and reporting calf and heifer experimental data. J. Dairy Sci. 87:3577-3580.

Kim, M.-H., J.-Y. Yang, S. D. Upadhay, H.-J. Lee, C.-H. Yun, and J. K. Ha. 2011. The stress of weaning influences serum levels of acute-phase proteins, iron-binding proteins, inflammatory cytokines, cortisol, and leukocyte subsets in Holstein calves. J. Vet. Sci. 12:151-157. https://doi.org/10.4142/jvs.2011.12.2.151.

Li, S., E. Khafipour, D. O. Krause, A. Kroeker, J. C. RodriguezLecompte, G. N. Gozho, and J. C. Plaizier. 2012. Effects of subacute ruminal acidosis challenges on fermentation and endotoxins in the rumen and hindgut of dairy cows. J. Dairy Sci. 95:294-303. https://doi.org/10.3168/jds.2011-4447.

Loberg, J. M., C. E. Hernandez, T. Thierfelder, M. B. Jensen, C. Berg, and L. Lidfors. 2008. Weaning and separation in two steps - A way to decrease stress in dairy calves suckled by foster cows. Appl. Anim. Behav. Sci. 111:222-234. https://doi.org/10.1016/j .applanim.2007.06.011.

Moisá, S. J., S. S. Aly, W. J. Love, T. W. Lehenbauer, P. H. Rossitto, A. L. Van Eenennaam, E. M. Bortoluzzi, S. C. Trombetta, and L. E. Hulbert. 2018. Association between plasma haptoglobin concentration and other biomarkers and bovine respiratory disease status in pre-weaned dairy calves. J. Vet. Diagn. Invest. 31:40-46. https: //doi.org/10.1177/1040638718807242.

Mojahedi, S., M. Khorvash, G. R. Ghorbani, E. Ghasemi, M. Mirzaei, and F. Hashemzadeh-Cigari. 2018. Performance, nutritional behavior, and metabolic responses of calves supplemented with forage depend on starch fermentability. J. Dairy Sci. 101:7061-7072. https://doi.org/10.3168/jds.2017-13798.

Murray, C. F., M. C. Windeyer, T. F. Duffield, D. B. Haley, D. L. Pearl, K. M. Waalderbos, and K. E. Leslie. 2014. Associations of serum haptoglobin in newborn dairy calves with health, growth, and mortality up to 4 months of age. J. Dairy Sci. 97:7844-7855. https://doi.org/10.3168/jds.2014-8465.

Murray, G. M., S. J. More, T. A. Clegg, B. Earley, R. G. O'Neill, D. Johnston, J. Gilmore, M. Nosov, M. C. McElroy, T. J. Inzana, and J. P. Cassidy. 2018. Risk factors associated with exposure to bovine respiratory disease pathogens during the peri-weaning period in dairy bull calves. BMC Vet. Res. 14:53. https://doi.org/ 10.1186/s12917-018-1372-9.

Nazari, M., K. Karkoodi, and A. Alizadeh. 2012. Performance and physiological responses of milk-fed calves to coated calcium butyrate supplementation. S. Afr. J. Anim. Sci. 42:296-303. https://doi .org/10.4314/sajas.v42i3.12.

Nejad, J. G., N. Torbatinejad, A. A. Naserian, S. Kumar, J. D. Kim, Y. H. Song, C. S. Ra, and K. I. Sung. 2012. Effects of process- ing of starter diets on performance, nutrient digestibility, rumen biochemical parameters and body measurements of Brown Swiss dairy calves. Asian-australas. J. Anim. Sci. 25:980-987. https:// doi.org/10.5713/ajas.2011.11457.

Obeidat, B. S., C. J. Cobb, M. D. Sellers, A. R. Pepper-Yowell, T. J. Earleywine, and M. A. Ballou. 2013. Plane of nutrition during the preweaning period but not the grower phase influences the neutrophil activity of Holstein calves. J. Dairy Sci. 96:7155-7166. https:/ /doi.org/10.3168/jds.2013-6699.

Owens, C. E., R. A. Zinn, A. Hassen, and F. N. Owens. 2016. Mathematical linkage of total tract digestion of starch and neutral detergent fiber to their fecal concentrations and the effect of site of starch digestion on extent of digestion and energetic efficiency of cattle. Prof. Anim. Sci. 32:531-549. https://doi.org/10.15232/pas .2016-01510.

Plaizier, J. C., E. Khafipour, S. Li, G. N. Gozho, and D. O. Krause. 2012. Subacute ruminal acidosis (SARA), endotoxins and health consequences. Anim. Feed Sci. Technol. 172:9-21. https://doi.org/ 10.1016/j.anifeedsci.2011.12.004.

Plaizier, J. C.. D. O. Krause, G. N. Gozho, and B. W. McBride. 2008. Subacute ruminal acidosis in dairy cows: The physiological causes, incidence and consequences. Vet. J. 176:21-31. https://doi.org/10 $.1016 /$ j.tvjl.2007.12.016.

Porter, J. C., R. G. Warner, and A. F. Kertz. 2007. Effect of fiber level and physical form of starter on growth and development of dairy calves fed no forage. Prof. Anim. Sci. 23:395-400. https://doi.org/ 10.15232/S1080-7446(15)30994-3.

Quigley, J. D., T. M. Hill, T. S. Dennis, F. X. Suarez-Mena, and R. L. Schlotterbeck. 2018. Effects of feeding milk replacer at 2 rates with pelleted, low-starch or texturized, high-starch starters on calf performance and digestion. J. Dairy Sci. 101:5937-5948. https:// doi.org/10.3168/jds.2017-13851.

Robertson, J. B., and P. J. Van Soest. 1981. The Detergent System of Analysis and its Application to Human Foods. Cornell University, Ithaca, NY.

Suarez-Mena, F. X., A. J. Heinrichs, C. M. Jones, T. M. Hill, and J. D. Quigley. 2015. Digestive development in neonatal dairy calves with either whole or ground oats in the calf starter. J. Dairy Sci. 98:3417-3431. https://doi.org/10.3168/jds.2014-9193.

Van Keulen, J. V., and B. A. Young. 1977. Evaluation of acid insoluble ash as a natural marker in ruminant digestibility studies. J. Anim. Sci. 44:282-287. https://doi.org/10.2527/jas1977.442282x.

Van Soest, P. J., J. B. Robertson, and B. A. Lewis. 1991. Methods for dietary fiber, neutral detergent fiber, non-starch polysaccharides in relation to animal nutrition. Symposium: carbohydrate methodology, metabolism and nutritional implications in dairy cattle. J. Dairy Sci. 74:3583-3597. https://doi.org/10.3168/jds.S0022 -0302(91)78551-2.

Wanat, P., P. Górka, and Z. M. Kowalski. 2015. Short communication: Effect of inclusion rate of microencapsulated sodium butyrate in starter mixture for dairy calves. J. Dairy Sci. 98:2682-2686. https: //doi.org/10.3168/jds.2014-8482.

Wildman, E. E., G. M. Jones, P. E. Wagner, R. L. Bowman, H. F. Troutt Jr., and T. N. Lesch. 1982. A dairy cow body condition scoring system and its relationship to selected production characteristics. J. Dairy Sci. 65:495-501. https://doi.org/10.3168/jds .S0022-0302(82)82223-6.

Yun, C.-H., P. Wynn, and J. K. Ha. 2014. Stress, acute phase proteins and immune modulation in calves. Anim. Prod. Sci. 54:1561-1568. https://doi.org/10.1071/AN14441. 